\title{
A revision of Neosclerus $V$. Thirteen new species and additional records (Coleoptera: Staphylinidae: Paederinae)
}

\author{
With 85 figures and 6 maps
}

VOLKER ASSING ${ }^{1}$

${ }^{1}$ Gabelsbergerstraße 2, 30163 Hannover, Germany. - vassing.hann@t-online.de Published on 2015-12-21

\section{Summary}

Thirteen species of Neosclerus CAmeron, 1924 are described and illustrated: N. albens spec. nov. (Sri Lanka), N. areolatus spec. nov. (Thailand), N. biangulatus spec. nov. (Thailand), N. daweianus spec. nov. (China: Yunnan), N. discolor spec. nov. (Burma, Thailand), N. figens spec. nov. (China: Yunnan), N. forficatus spec. nov. (Sri Lanka), N. fractus spec. nov. (India: Meghalaya), N. khasicus spec. nov. (India: Meghalaya), N. revolutus spec. nov. (South India), N. sagittatus spec. nov. (India: Meghalaya), N. semicalvus spec. nov. (Thailand), and N. trisinuatus spec. nov. (China: Yunnan). The previously unknown male sexual characters of $N$. granulicollis CAMERON, 1924 are described and illustrated. Additional records of twelve named and three unnamed species are reported, among them several new country records. The genus now comprises 44 named species in five species groups, one of them newly established. The countries with the greatest diversity are China, India, and Thailand (ten species each), and Taiwan (nine locally endemic species). The distribution of the genus as a whole, as well as the individual distributions of 34 species are mapped. An updated catalogue is provided.

\section{Key words}

Coleoptera, Staphylinidae, Paederinae, Medonina, Neosclerus, East Palaearctic region, Oriental region, taxonomy, new species, new records, species groups, zoogeography, distribution maps, catalogue

\section{Zusammenfassung}

Dreizehn Arten der Gattung Neosclerus CAmeron, 1924 werden beschrieben und abgebildet: N. albens spec. nov. (Sri Lanka), N. areolatus spec. nov. (Thailand), N. biangulatus spec. nov. (Thailand), N. daweianus spec. nov. (China: Yunnan), N. discolor spec. nov. (Burma, Thailand), N. figens spec. nov. (China: Yunnan), N. forficatus spec. nov. (Sri Lanka), N. fractus spec. nov. (Indien: Meghalaya), N. khasicus spec. nov. (Indien: Meghalaya), N. revolutus spec. nov. (Südindien), N. sagittatus spec. nov. (Indien: Meghalaya), N. semicalvus spec. nov. (Thailand) und N. trisinuatus spec. nov. (China: Yunnan). Die zuvor unbekannten männlichen Sexualmerkmale von N. granulicollis CAMERON, 1924 werden beschrieben und abgebildet. Weitere Nachweise von fünfzehn Arten, davon drei unbenannt, werden gemeldet, darunter mehrere Erstnachweise. Einschließlich der neuen Arten enthält die Gattung derzeit 44 beschriebene Arten in fünf Artengruppen, von denen eine neu begründet wird. Die Diversität ist in China, Indien und Thailand (je zehn Arten) sowie in Taiwan (neun lokalendemische Arten) am höchsten. Die derzeit bekannte Gesamtverbreitung der Gattung sowie die Verbreitungsgebiete von 34 Arten werden anhand von Karten illustriert. Ein aktualisierter Katalog wird erstellt. 


\section{Introduction}

The distribution of the medonine genus Neosclerus CAmeron, 1924 includes the southern East Palaearctic and the Oriental regions, and ranges from the Himalaya (North India, Nepal, Bhutan), Burma, and southern China in the north to South India, Sri Lanka, Borneo, Java, and Sumatra in the south. The genus previously included a total of 31 species. The regions with the greatest diversity were Taiwan (nine species) and southern China (seven species). A catalogue and a key to species were provided by Assing (2011a). The species have been attributed to four species groups, with some species of uncertain affiliations (male sexual characters unknown) (Assing 2011a, 2011b, 2013, 2014).

The present paper is based on material collected during a recent field trip to East Yunnan conducted by Michael Schülke and the author, as well as on more than 500 previously unrevised specimens from the Muséum d'Histoire Naturelle, Genève. A study of this material, in total 651 specimens, yielded an astounding thirteen species new to science, the previously unkown male of N. granulicollis CAmeron, 1924, as well as additional records of twelve previously described species and records of three unnamed species, at least one of them undescribed.

\section{Material and methods}

The material treated in this study is deposited in the following collections:

\section{MHNG Muséum d'Histoire Naturelle, Genève (G. Cuccodoro)}

MNHUB Museum für Naturkunde der HumboldtUniversität Berlin (J. Frisch, J. Willers)

cAss author's private collection

cSch private collection Michael Schülke, Berlin

The morphological studies were conducted using a Stemi SV 11 microscope (Zeiss Germany) and a Jenalab compound microscope (Carl Zeiss Jena). The images of the forebodies were created using a photographing device constructed by Arved Lompe (Nienburg) and CombineZ software. A digital camera (Nikon Coolpix 995) was used for the remaining photographs. The maps were created using MapCreator 2.0 (primap) software.

Body length was measured from the anterior margin of the mandibles (in resting position) to the abdominal apex, the length of the forebody from the anterior margin of the mandibles to the posterior margin of the elytra, head length from the anterior margin of the frons to the posterior constriction of the head, elytral

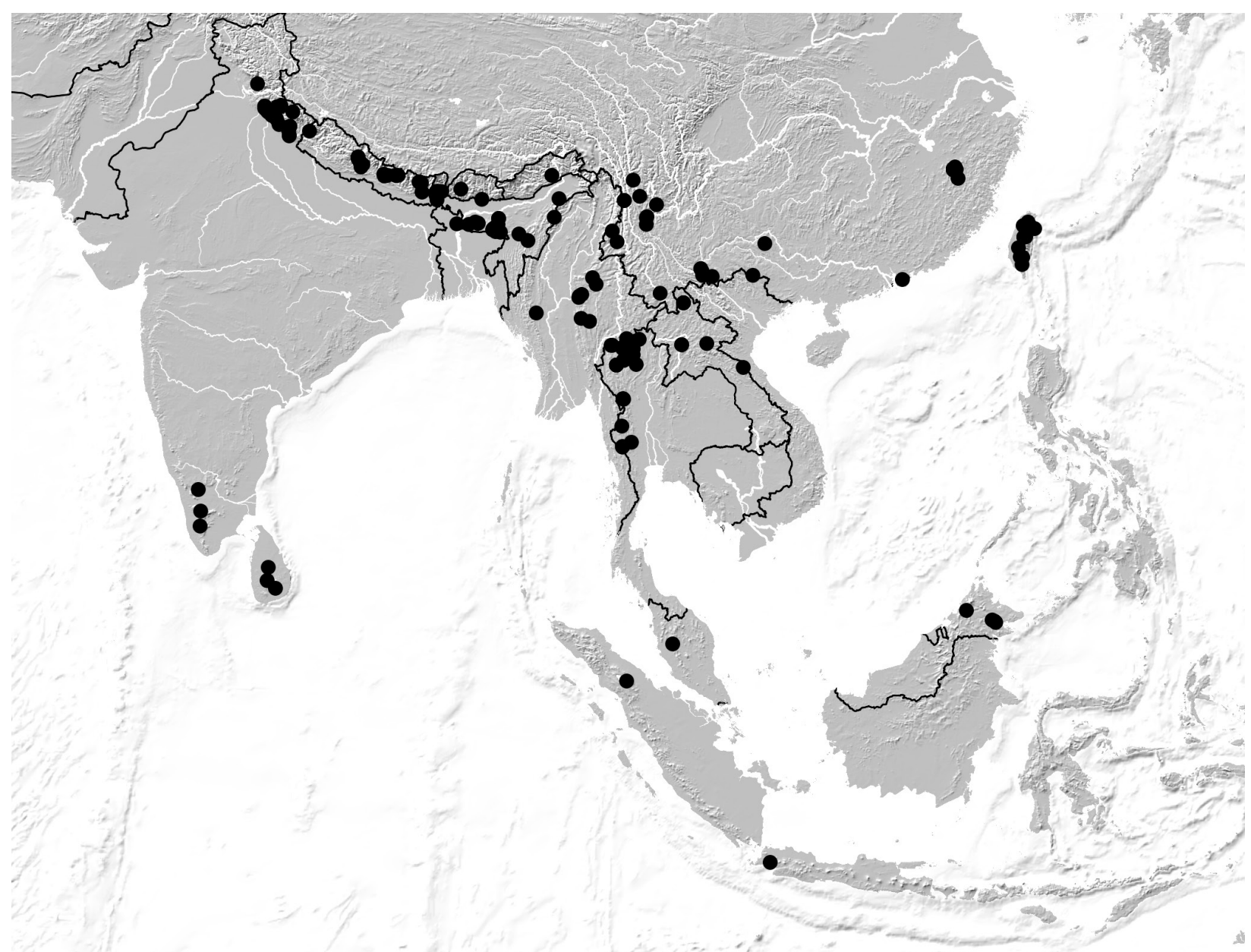

Map 1: Pooled distribution of Neosclerus in the Oriental and southern East Palaearctic regions, based on examined records. 
length at the suture from the apex of the scutellum to the posterior margin of the elytra (at the suture), and the length of the aedeagus from the apex of the ventral process to the base of the aedeagal capsule. The "parameral" side (i.e., the side where the sperm duct enters) is referred to as the ventral, the opposite side as the dorsal aspect.

\subsection{General remarks}

Including the newly described species, Neosclerus now comprises a total of 44 species in five species groups. One of them, the $N$. granulicollis group, is newly established with $N$. granulicollis as the sole representative.

The general distribution of the genus (Map 1) still shows some evident gaps, particularly in the central and southern parts of India, in the southern Indochinese Peninsula, in Malaysia, and in Indonesia. Most Neosclerus species are fully winged, more or less widespread (though partly known only from few localities), and their distributions often overlap. At least three species are wing-dimorphic. Micropterous, locally endemic species are known from Northeast India (Meghalaya), South China, and particularly from Taiwan, where macropterous species are apparently absent.

The countries with the greatest diversity are China, Thailand, and India (ten species each), followed by Taiwan (nine locally endemic species), Burma (five species), Laos and Nepal (four species each), Sri Lanka (three endemic species), Malaysia (three species), Indonesia (two species), and Bhutan, Vietnam, and Hongkong (one species each).

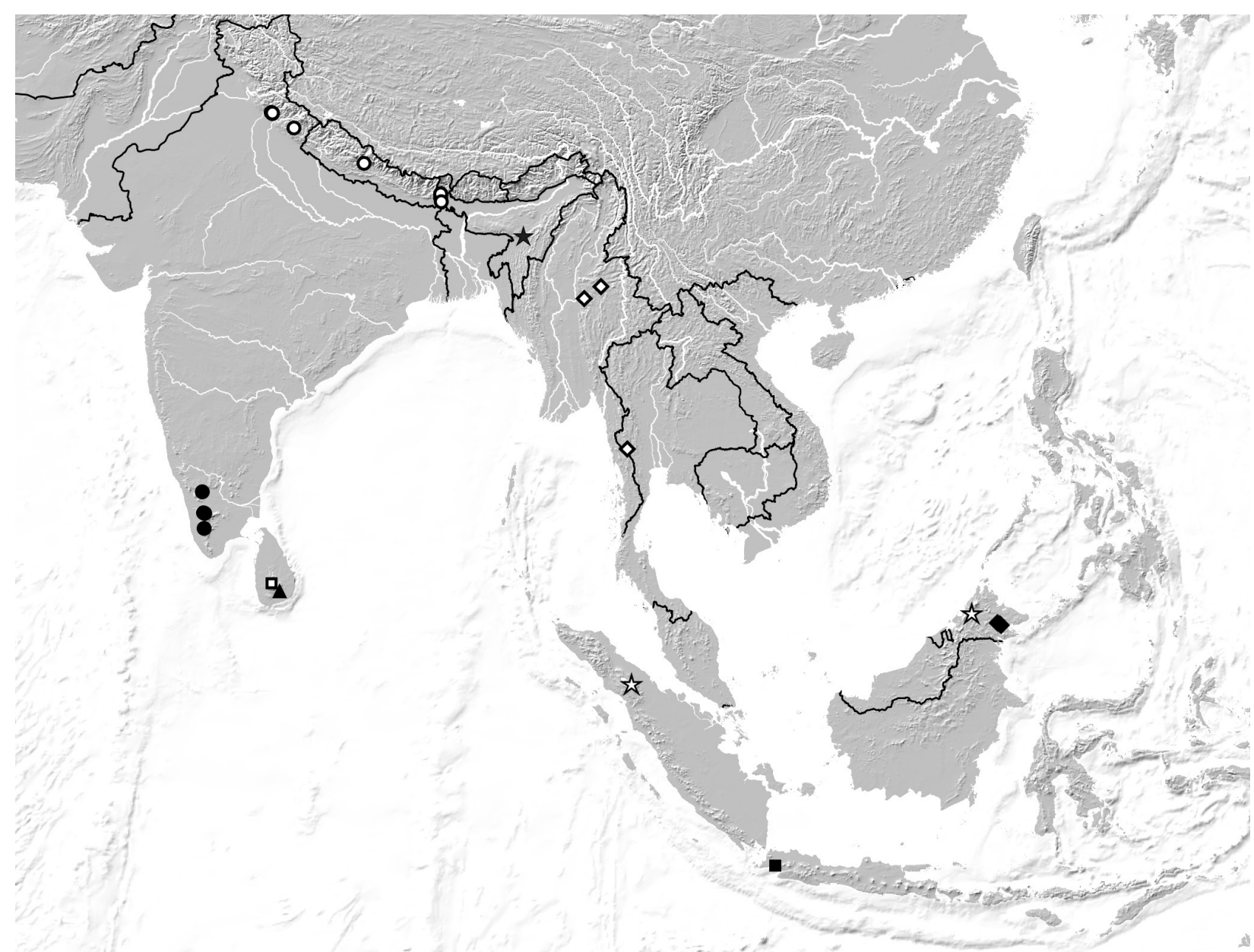

Map 2: Distributions of the species of the N.fortepunctatus group, except N. dupleseriatus: N. fortepunctatus (white circles); N. obscurus (black star); N. barbatus (white diamonds); N. revolutus (black circles); N. nigerrimus (question mark; precise locality in Sri Lanka unknown); N. albens (white square); N. forficatus (black triangle); N. immutatus (white stars); N. erubescens (black diamonds); N. javanus (black square). 


\subsection{Descriptions and additional records}

\subsubsection{Neosclerus fortepunctatus group}

\section{Neosclerus fortepunctatus CAMERON, 1924 (Map 2)}

Material examined: India: Uttar Pradesh: 16 exs., Garhwal, road to Mussoorie, 1300 m, 18.X.1979, leg. Löbl (MHNG, cAss); 1 , Garhwal, below Mussoorie, 1700 m, 19.X.1979, leg. Löbl (MHNG). West Bengal: Darjeeling: 2 exs., 13 km N Ghoom, 1500 m, 15.X.1978, leg. Besuchet \& Löbl (MHNG, cAss); 2 우 오 Mahanadi, 1200 m, 19.X.1978, leg. Besuchet \& Löbl (MHNG); 1 ㅇ, Ghoom-Lopchu, 2000 m, 14.X.1978, leg. Besuchet \& Löbl (MHNG); 5 exs., Sukna, 200 m, 7.X.1978, leg. Besuchet \& Löbl (MHNG, cAss).

Comment: Male-based records of $N$. fortepunctatus were previously known only from the environs of Mussoorie in Uttar Pradesh (India) and Pokhara in central Nepal (Assing 2011a, b). The specimens from Darjeeling considerably expand the known range towards the east (Map 2). The distribution of $N$. fortepunctatus overlaps with that of the highly similar, closely related, and much more common N.dupleseriatus, as well as with that of N. granulicollis.

\section{Neosclerus dupleseriatus Assing, 2011 (Map 3)}

Material examined: India: Uttar Pradesh: 15 exs., Kumaon, Rangarh, 2000 m, 9.X.1979, leg. Löbl (MHNG, cAss); 3 exs., Kumaon, Bhim Tal env., 1500 m, 4.X.1979, leg. Löbl (MHNG, cAss); 3 exs., same data, but $1800 \mathrm{~m}$ (MHNG); 6 exs., Kumaon, Chaubattia near Ranikhet, 1800 m, 12.-13.X.1979, leg. Löbl (MHNG, cAss); 16 exs., Kumaon, between Bhim Tal and Sat Tal, 1500 m, 7.X.1979, leg. Löbl (MHNG, cAss); 3 exs., Garhwal, below Bhatwari, 1500 m, 24.X.1979, leg. Löbl (MHNG, cAss); 36 exs., Garhwal, 4 km S Bhatwari, 1400 m, 23.X.1979, leg. Löbl (MHNG, cAss); 6 exs., Garhwal, below Joshimath, 2100 m, 27.X.1979, leg. Löbl (MHNG, cAss); 152 exs., Garhwal, above Pauri, 1900 m, 28.X.1979, leg. Löbl (MHNG, cAss); 3 exs., Garhwal, 20 km S Chamba, 1150 m, 20.X.1979, leg. Löbl (MHNG, cAss); 4 exs., Garhwal, 16 km from Karnaprayag, Chamoli env., 900 m, 26.X.1979, leg. Löbl (MHNG, cAss). Nepal: 21 exs. [all macropterous], Bagmati province, Dobate Ridge NE Barahbise, 2700 m, 2.V.1981, leg. Löbl \& Smetana (MHNG, cAss); 13 exs. [all macropterous], Bagmati province, Pokhare NE Barahbise, 2800 m, 2.V.1981, leg. Löbl \& Smetana (MHNG, cAss); 1 ㅇ, Bagmati province, Nagarjun Forest near Kathmandu, 1650 m, 2.IV.1981, leg. Löbl \& Smetana (MHNG); $1 \sigma^{\star}$, Kosi, Induwa Khola valley, 2100 m, 17.IV.1984, leg. Löbl \& Smetana (cAss).

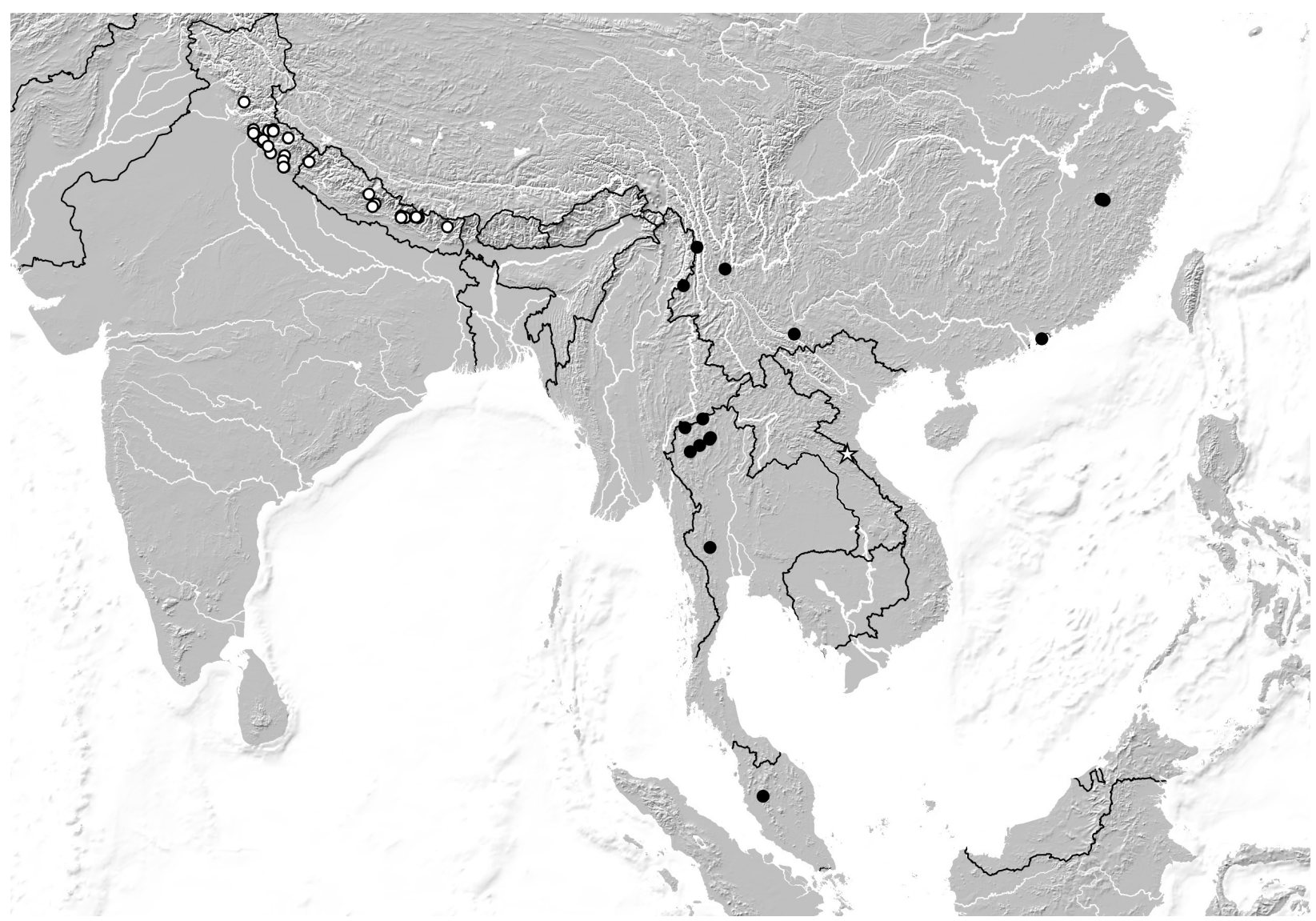

Map 3: Distributions of N. dupleseriatus (white circles), N. glaber (black circles), and N. bicarinatus (white star). 
Comment: Neosclerus dupleseriatus is the most common species of the genus in the Himalaya from Northwest India to Nepal. The above specimen from Kosi considerably expands the known distribution eastwards. The currently known distribution is illustrated in Map 3.

\section{Neosclerus barbatus Assing, 2011 (Map 2)}

Material examined: Burma: 1 ex., Maymyo env., 700-900 m, 4.-5.III.1996, leg. Kurbatov (MHNG); 1 ex., Shan province, Hsipaw, ca. 600 m, 22.II.1996, leg. Kurbatov (cAss)

Comment: Like the two preceding species, N. barbatus belongs to the $N$. fortepunctatus group. It was previously represented only by the holotype from Thailand. The distribution is illustrated in Map 2.

\section{Neosclerus revolutus spec. nov.}

(Figs 1-5, Map 2)

Type material: Holotype ơ: "INDIA N. 18 Kerala, Cardamon H. entre Pambanar et Peermade, 950 m, 9-XI-72, Besuchet Löbl Mussard / Holotypus ơ Neosclerus revolutus spec. nov. det. V. Assing 2015" (MHNG).

Paratypes: 10 exs.: same data as holotype (MHNG, cAss) 5 exs.: "INDIA Kerala, Nelliampathi Hills, N.O. Anaimalai Hills, 900 m 30-XI-72, Besuchet Löbl Mussard" (MHNG, cAss); 7 exs.: "INDIA Madras, No. 38, Nilgiri 7 km E. de Conoor, $1350 \mathrm{~m}, 19-\mathrm{XI}-72$, Besuchet Löbl Mussard" (MHNG, cAss); 2 exs.: "INDIA 39 Madras, Anaimalai H. Valparai, 1100 m. 20-XI-72, Besuchet Löbl Mussard" (MHNG, cAss).

Etymology: The specific epithet is the past participle of the Latin verb revolvere (to roll, to coil) and alludes to the basally coiled internal structures of the aedeagus.

Description: Body length 3.1-3.9 mm; length of forebody $1.8-2.0 \mathrm{~mm}$. Coloration: head and pronotum blackish; elytra and abdomen brown to blackish-brown; legs yellowish; antennae reddish to reddish-brown.

Head (Fig. 1) relatively weakly transverse, 1.07-1.10 times as broad as long; punctation coarse and dense in anterior portion, distinctly less dense to very sparse and moderately coarse to fine in posterior portion of dorsal surface; interstices without microsculpture. Eyes separated from posterior angles by a distance of distinctly more than the width of antennomere II. Antenna approximately $1.0 \mathrm{~mm}$ long.

Pronotum (Fig. 1) 1.05-1.10 times as long as broad and about 0.85 times as broad as head; punctation coarse and moderately dense; midline broadly impunctate; interstices without microsculpture.
Elytra (Fig. 1) approximately as long as pronotum; punctation rather coarse and very dense. Hind wings present. Metatarsomere I nearly as long as the combined length of II and III.

Abdomen narrower than elytra; punctation fine, moderately dense on anterior tergites, gradually becoming sparser towards posterior tergites; interstices with distinct microsculpture; posterior margin of tergite VII with palisade fringe.

$0^{\top}$ : sternite VII (Fig. 2) approximately 1.2 times as broad as long, posterior margin broadly and distinctly concave, pubescence unmodified; sternite VIII (Fig. 2) distinctly oblong and with unmodified pubescence, posterior excision of broadly triangular shape, its depth approximately one-seventh the length of sternite; aedeagus (Figs 4-5) $0.65-68 \mathrm{~mm}$ long (approximately $0.6 \mathrm{~mm}$ in dry preparation) and rather weakly sclerotized; ventral process long and slender, apically hooked in lateral view; internal sac with a pair of long series of weakly sclerotized structures.

Comparative notes: As can be inferred particularly from the male sexual characters (shapes and chaetotaxy of sternite VII and VIII, morphology of the aedeagus), $N$. revolutus belongs to the $N$. fortepunctatus group. It is distinguished from other species of this group particularly by the densely and coarsely punctate, practically matt elytra, the relatively sparsely punctate posterior portion of the head, the broadly and distinctly concave posterior margin of the male sternite VII, and by the shape and internal structures of the aedeagus. The general shape of the aedeagus is most similar to that of $N$. fortepunctatus, N. barbatus, and N. obscurus Assing, 2013. For illustrations of these species see Assing (2011a, 2013).

Distribution and natural history: The type specimens were collected in two localities in Tamil Nadu and two in Kerala, South India (Map 2), at altitudes of 900-1350 m.

\section{Neosclerus forficatus spec. nov. (Figs 6-11, Map 2)}

Type material: Holotype $0^{\text {*: }}$ "CEYLAN Uva, s/Wellawaya, 300 m, 25.I.70, Mussard Besuchet Löbl / Holotypus o Neosclerus forficatus spec. nov. det. V. Assing 2015" (MHNG).

Paratype 9 : same data as holotype (cAss).

Etymology: The specific epithet is an adjective derived from the Latin noun forfex (pliers, forceps) and alludes to the shape of the basal internal structures of the aedeagus.

Description: Small species; body length $2.7-3.0 \mathrm{~mm}$; length of forebody $1.4-1.5 \mathrm{~mm}$. Coloration: body blackish-brown to blackish, with the elytra slightly paler; legs pale-yellowish; antennae dark-yellowish. 


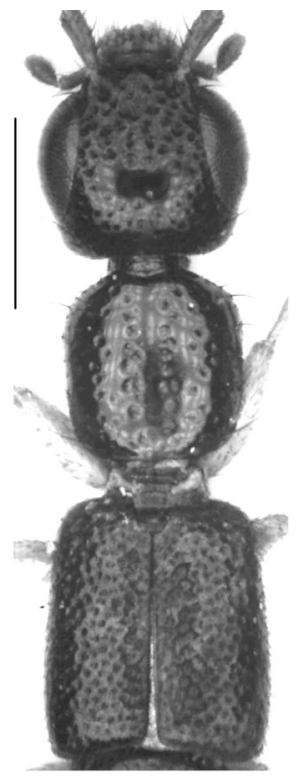

1

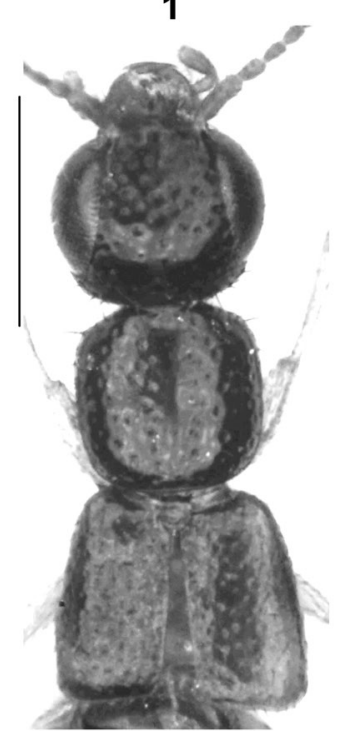

6

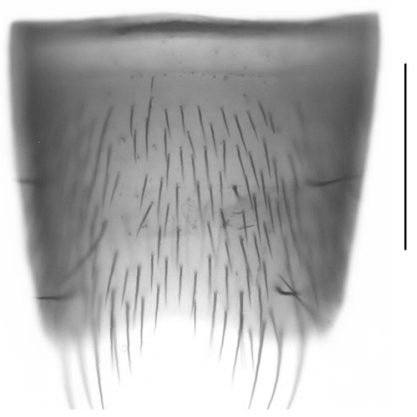

2

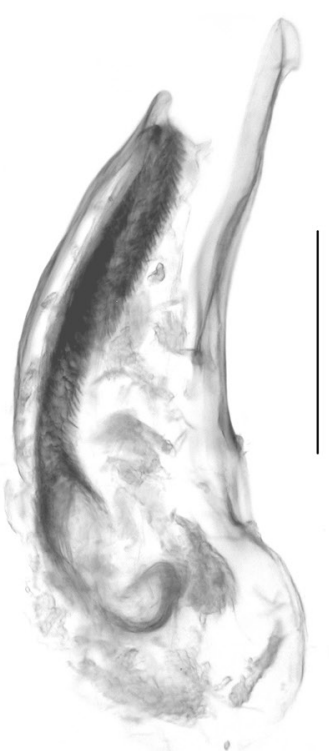

4

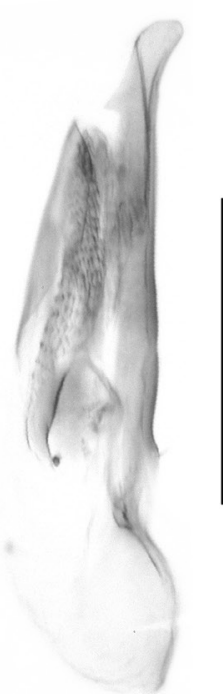

9

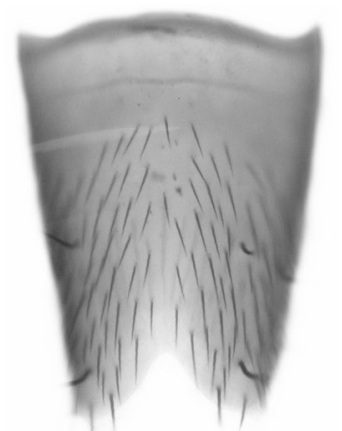

3

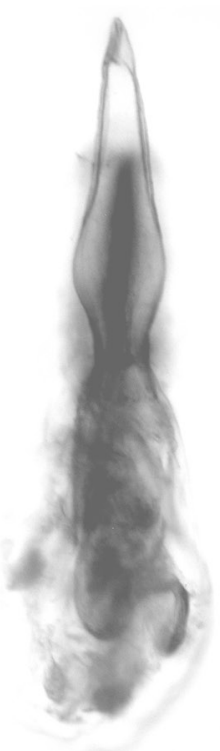

5

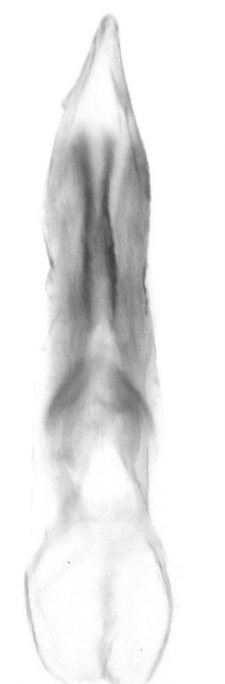

10

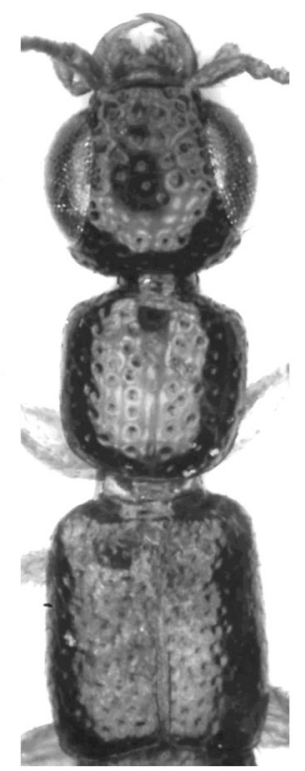

12

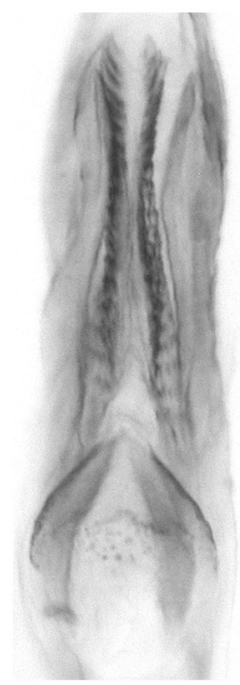

11

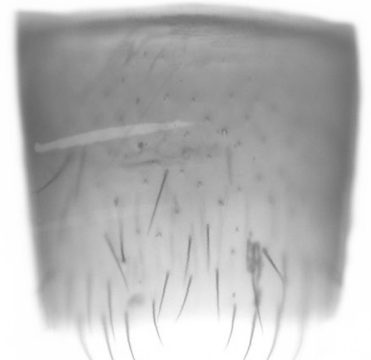

13

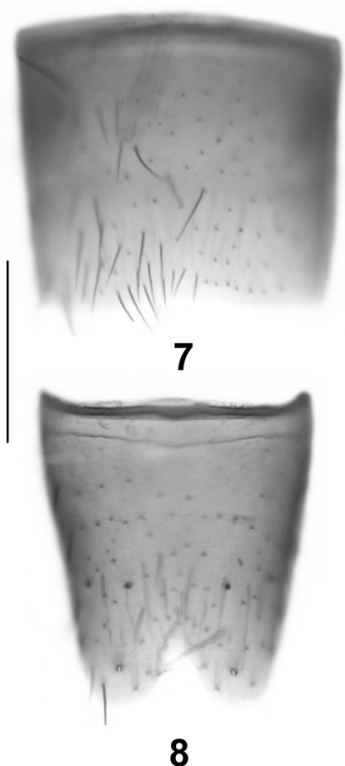

8

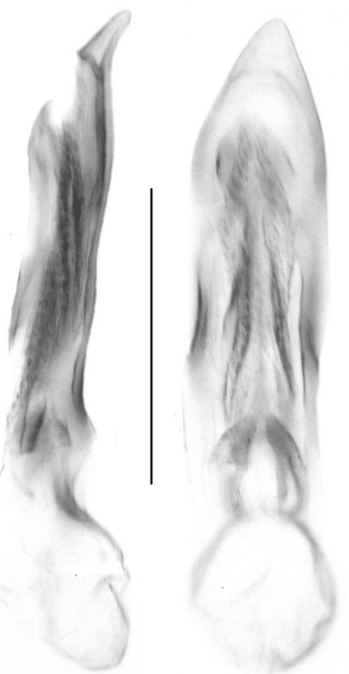

15

16

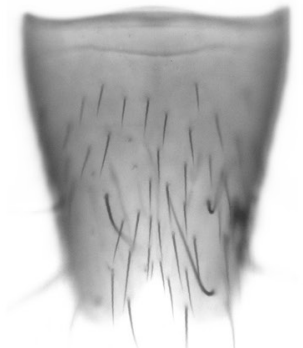

14

Figs 1-16: Neosclerus revolutus spec. nov. (1-5), N. forficatus spec. nov. (6-11), and N. albens spec. nov. (12-16): forebody (1, 6, $12)$; male sternite VII $(2,7,13)$; male sternite VIII $(3,8,14)$; aedeagus in lateral and in ventral view $(4-5,9-10,15-16)$; internal structures of aedeagus in ventral view (11). Scale bars: 1, 6, 12: $0.5 \mathrm{~mm} ; 2-5,7-19,13-16: 0.2 \mathrm{~mm}$; 11:0.1 mm. 
Head (Fig. 6) relatively weakly transverse, approximately 1.1 times as broad as long; punctation moderately coarse and moderately dense in anterior half, sparser and less coarse in posterior half of dorsal surface; interstices without microsculpture. Eyes separated from posterior angles by a distance of slightly more than width of antennomere II. Antenna approximately $0.75 \mathrm{~mm}$ long.

Pronotum (Fig. 6) approximately as broad as long and about 0.85 times as broad as head; on either side of the broadly impunctate midline with a series of approximately 10 punctures, lateral portion with rather sparse coarse punctation; interstices without microsculpture. Elytra (Fig. 6) relatively short, approximately 0.9 times as long as pronotum; punctation moderately fine and moderately dense. Hind wings completely reduced. Metatarsomere I nearly as long as the combined length of II and III.

Abdomen approximately as broad as elytra; punctation fine, rather dense on anterior tergites, gradually becoming less dense towards posterior tergites; interstices with shallow microsculpture; posterior margin of tergite VII with palisade fringe.

$0^{7}$ : sternite VII (Fig. 7) 1.23 times as broad as long, posterior margin weakly concave in the middle, pubescence unmodified; sternite VIII (Fig. 8) weakly oblong and with unmodified pubescence, posterior excision of triangular shape, its depth approximately one-fifth the length of sternite; aedeagus (Figs 9-10) $0.45 \mathrm{~mm}$ long and weakly sclerotized; ventral process long and slender, apically acute in ventral view; internal sac with a pair of series of weakly sclerotized structures and with a basal pair of weakly sclerotized sclerites (Fig. 11).

Comparative notes: Based on external (head weakly transverse; head moderately bulging and clearly not reaching posterior angles; punctation of forebody moderately dense) and the male sexual characters (sternites VII and VIII with unmodified pubescence; aedeagus with dorso-ventrally flattened ventral process; internal sac with two long series of membranous structures and a pair of basal sclerites), $N$. forficatus is closely allied to $N$. nigerrimus (KRAATZ, 1859), previously the sole representative of the genus known from Sri Lanka. The new species is distinguished from $N$. nigerrimus by the much more slender and apically more acute ventral process, as well as the more or less sclerotized and differently shaped pair of basal internal structures of the aedeagus.

The unmodified pubescence of the male sternite VIII and the morphology of the aedeagus (ventral process dorso-ventrally flattened; internal sac with a pair of series of membranous structures) suggest that both $N$. nigerrimus and $N$. forficatus belong to the $N$. fortepunctatus group.

Distribution and natural history: The type locality is situated in the southeast of Sri Lanka (Map 2) at an altitude of $300 \mathrm{~m}$.

\section{Neosclerus albens spec. nov.}

(Figs 12-16, Map 2)

Type material: Holotype ơ: "CEYLAN Central, s/ Mululla, 750 m, 4.II.70, Mussard Besuchet Löbl / Holotypus $0^{*}$ Neosclerus albens spec. nov. det. V. Assing 2015” (MHNG).

Paratypes: 2 ㅇ + : same data as holotype (MHNG, cAss).

Etymology: The specific epithet (Latin, adjective: pale) alludes to the weakly sclerotized aedeagus.

Description: Small species; body length 2.7-3.0 mm; length of forebody $1.5-1.6 \mathrm{~mm}$. External characters (Fig. 12) as in N. forficatus, except as follows:

Head (Fig. 12) anteriorly with relatively sparse and coarse punctures, punctation of pronotum and of remainder of head not particularly coarse and rather sparse. Elytra apparently dimorphic, approximately 1.1 times as long as pronotum in holotype (macropterous morph) and 0.9 times as long as pronotum in paratypes (brachypterous morph). Hind wings probably fully developed in macropterous morph, of reduced length (extending slightly beyond posterior margin of elytra) in brachypterous morph.

$\sigma^{7}$ : sternite VII (Fig. 13) 1.28 times as broad as long, posterior margin very weakly concave in the middle, pubescence sparse and unmodified; sternite VIII (Fig. 14) 1.1 times as long as broad and with unmodified pubescence, posterior excision of triangular shape, its depth approximately one-sixth the length of sternite; aedeagus (Figs 15-16) $0.45 \mathrm{~mm}$ long and weakly sclerotized; ventral process long and slender, apically moderately acute in ventral view; internal sac with a pair of series of weakly sclerotized structures and with a basal pair of weakly sclerotized sclerites.

Comparative notes: This species, too, is closely allied to $N$. nigerrimus, as can be inferred from the similar external and male sexual characters. It is distinguished from $N$. nigerrimus by the less broad posterior excision of the male sternite VIII, the more slender ventral process of the aedeagus ( $N$. nigerrimus: distinctly dilated subapically in ventral view) and by the weakly sclerotized and differently shaped basal internal structures of the aedeagus. For illustrations of N. nigerrimus see AssiNG (2011a).

Distribution and natural history: The type locality is situated in Central Province, Sri Lanka (Map 2), at an altitude of $750 \mathrm{~m}$. 


\subsubsection{Neosclerus granulicollis group}

Neosclerus granulicollis CAMERON, 1924

(Figs 47-50, Map 4)

Material examined: India: West Bengal: Darjeeling: 2 exs., Ghoom, 1500 m, 15.X.1978, leg. Besuchet \& Löbl (MHNG); 1 ex., 13 km N Ghoom, 1500 m, 15.X.1978, leg. Besuchet \& Löbl (cAss); 1 ex., Ghoom-Lopchu, 2000 m, 14.X.1978, leg. Besuchet \& Löbl (MHNG); 1 ex., Algarah, 1800 m, 9.X.1978, leg. Besuchet \& Löbl (cAss).

Comment: This species was originally described from Uttar Pradesh and subsequently reported also from West Bengal, as well as from Central and East Nepal (Assing 2011a, b). The distribution (Map 4) is largely congruent with those of $N$. fortepunctatus and $N$. dupleseriatus.

The male sexual characters were previously unknown; the aedeagus of the available male was teratologically malformed, at least that is what I had believed. Based on the above material, the male sexual characters, especially the aedeagus, are remarkably different from those of all other Neosclerus species:

sternite VII (Fig. 47) weakly transverse, with unmodified pubescence, and with weakly concave posterior margin; sternite VIII (Fig. 48) strongly oblong, posterior margin with shallow median concavity, without distinct excision; aedeagus (Figs 49-50) minute, only approximately $0.3 \mathrm{~mm}$ long, very weakly sclerotized, and with very short and apically broadly convex (ventral view) ventral process; internal sac with weakly defined structures.
The general morphology of the aedeagus and the punctation of the pronotum are unique in the genus, suggesting that $N$.granulicollis represents a species group of its own.

\subsubsection{Neosclerus glaber group}

\section{Neosclerus glaber Assing, 2011 \\ (Map 3)}

Material examined: China: $2 \sigma^{\star} \sigma^{\star}, 4$ ㅇ + [all more or less teneral], Yunnan, S Gejiu, $23^{\circ} 17^{\prime} \mathrm{N}, 103^{\circ} 09^{\prime} \mathrm{E}, 1860 \mathrm{~m}$, grassy slope with shrubs near road, litter, soil, and moss sifted, 21.VIII.2014, leg. Schülke (cSch, cAss). Thailand: 1 ơ $^{\star}$, Chiang Mai, Doi Suthep, 890 m, pitfall trap, IV.1986, leg. Schwendinger (cAss); 1 o , 3 우 우 [1 teneral], Chiang Mai, Doi Suthep, 1450 m, 4.XI.1985, leg. Burckhardt \& Löbl (MHNG); 1 ㅇ, Chiang Mai, Doi Inthanon, 1080 m, 24.XI.1987, leg. Schwendinger (MHNG); 1 \% , Chiang Mai, Doi Inthanon, 1780 m, 17.XII.1986, leg. Schwendinger (MHNG); 1 ㅇ, Chiang Mai, Doi Inthanon, 172 m, 7.XI.1985, leg. Schwendinger (MHNG); $10^{\star}$, Chiang Mai, Doi Inthanon, 910 m, 23.II.1987, leg. Schwendinger (cAss); 1 + , Chiang Mai, 50 km NE Chiang Mai, road to Wab Pang An, 900 m, 3.XI.1985, leg. Burckhardt \& Löbl (MHNG); 1 đ̊ , Chiang Mai, 54 km NE Chiang Mai, Mae Nang Kaeo, 900 m, 3.XI.1985, leg. Burckhardt \& Löbl (MHNG); 1 ๙, Chiang Mai, Doi Angkhang, 10 km W Fang, 920 m, 18.III.1987, leg. Schwendinger (cAss); $10^{\star}$, Kanchanapuri Province, Chalerm Rattana Kosin, 12.XI.1992, leg. Schwendinger (MHNG); 1 ㅇ, Mae Hong

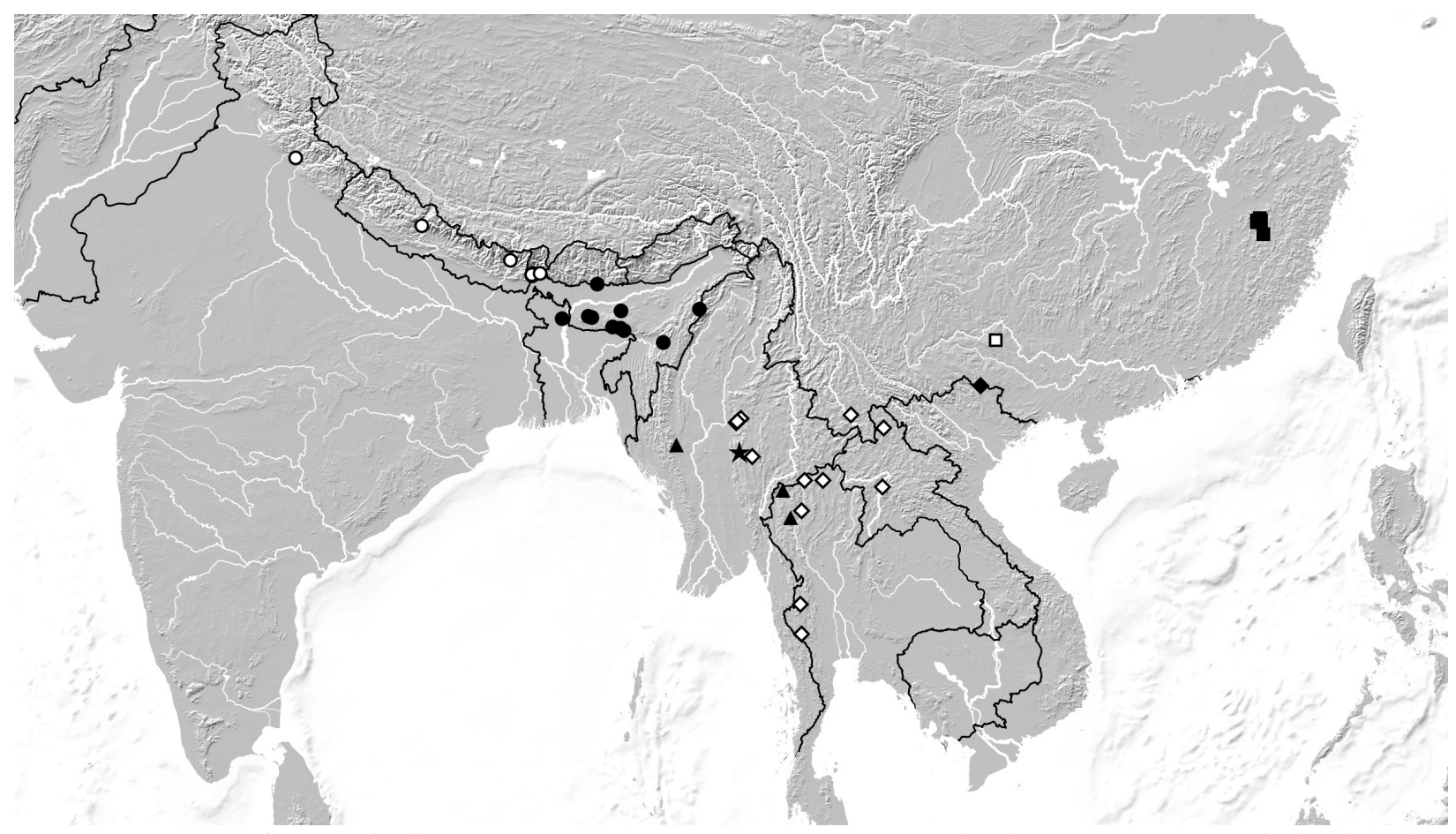

Map 4: Distributions of N. granulicollis (white circles), N. assamensis (black circles), N. discolor (black triangles), N. barbatulus (white diamonds), N. schillhammeri (black star), $N$. incisus (black diamond), $N$. rimatus (white square), and $N$. hlavaci (black squares). 
Son, 8 km N Mae Lang, Tom Lok, 700 m, 13.XI.1985, leg. Burckhardt \& Löbl (MHNG).

Comment: The known distribution of $N$. glaber includes southern China (Yunnan, Fujian), Hong Kong, Thailand, and Malaysia (Map 3).

\section{Neosclerus macer Assing, 2013}

(Map 5)

Material examined: Thailand: $20^{x} o^{x}, 2+\circ$, Chiang Rai, 10 km W Wiang Pa Pao, Ban Huay Ya Sai, 780 m, 28.I.1988, leg. Schwendinger (MHNG, cAss); 1 ㅇ, Chiang Mai, Doi Chiang Dao, 16.X.1986, leg. Schwendinger (MHNG); 1 ㅇ, $50 \mathrm{~km} \mathrm{~N} \mathrm{Lampang,} \mathrm{Pratu} \mathrm{Pah,} 620$ m, sifted, 18.I.1986, leg. Schwendinger (MHNG).

Comment: This species was previously represented only by the holotype from Laos (Assing 2013). The currently known distribution is illustrated in Map 5.

\subsubsection{Neosclerus brevipennis group}

\section{Neosclerus brevipennis (CAMERON, 1943)} (Map 3)

Material examined: India: West Bengal: Darjeeling 8 exs., Teesta, 250 m, 10.X.1978, leg. Besuchet \& Löbl (MHNG, cAss); 1 + , Singla, 300 m, 17.X.1978, leg. Besuchet \& Löbl (MHNG); $2 \sigma^{\star} o^{\star}$, Kalimpong, 1300 m,
11.X.1978, leg. Besuchet \& Löbl (cAss). Meghalaya: 7 exs., Khasi Hills, Nongpoh, 700 m, 5.XI.1978, leg. Besuchet \& Löbl (MHNG, cAss); 17 exs., Garo Hills, Tura, 700-900 m, 1.XI.1978, leg. Besuchet \& Löbl (MHNG, cAss); 1 ㅇ, Garo Hills, Darogiri, 400 m, 4.XI.1978, leg. Besuchet \& Löbl (MHNG). Nepal: 8 exs., Kosi, Arun valley, S Num, 1050 m, 20.IV.1984, leg. Löbl \& Smetana (MHNG, cAss).

Comment: The known distribution of $N$. brevipennis, like N. dupleseriatus a wing-dimorphic species, ranges from East Nepal and West Bengal to Bhutan, Assam, Meghalaya, and Arunachal Pradesh (Map 5).

\section{Neosclerus assamensis (CAMERON, 1931)} (Map 4)

Material examined: India: Meghalaya: 17 exs. [partly teneral], Garo Hills, Songsak, 400 m, 2.XI.1978, leg. Besuchet \& Löbl (MHNG, cAss); 3 exs., Garo Hills, Darugiri, 400 m, 4.XI.1978, leg. Besuchet \& Löbl (MHNG, cAss); 3 exs. [1 teneral], Garo Hills, Rongrengiri, 400 m, 3.XI.1978, leg. Besuchet \& Löbl (MHNG, cAss); 4 exs., Khasi Hills, Nongpoh, 700 m, 5.XI.1978, leg. Besuchet \& Löbl (MHNG, cAss); 1 ex., Khasi Hills, Dawki, 500-800 m, 29.X.1978, leg. Besuchet \& Löbl (cAss); 4 exs., Khasi Hills, Mawsynram-Balat, 1000 m, 27.X.1978, leg. Besuchet \& Löbl (MHNG, cAss); 12 exs., Khasi Hills, Pynursla, 1100 m, 29.X.1978, leg. Besuchet \& Löbl (MHNG, cAss). Assam: 1 + , Manas, 200 m, 22.X.1978, leg. Besuchet \& Löbl (MHNG).

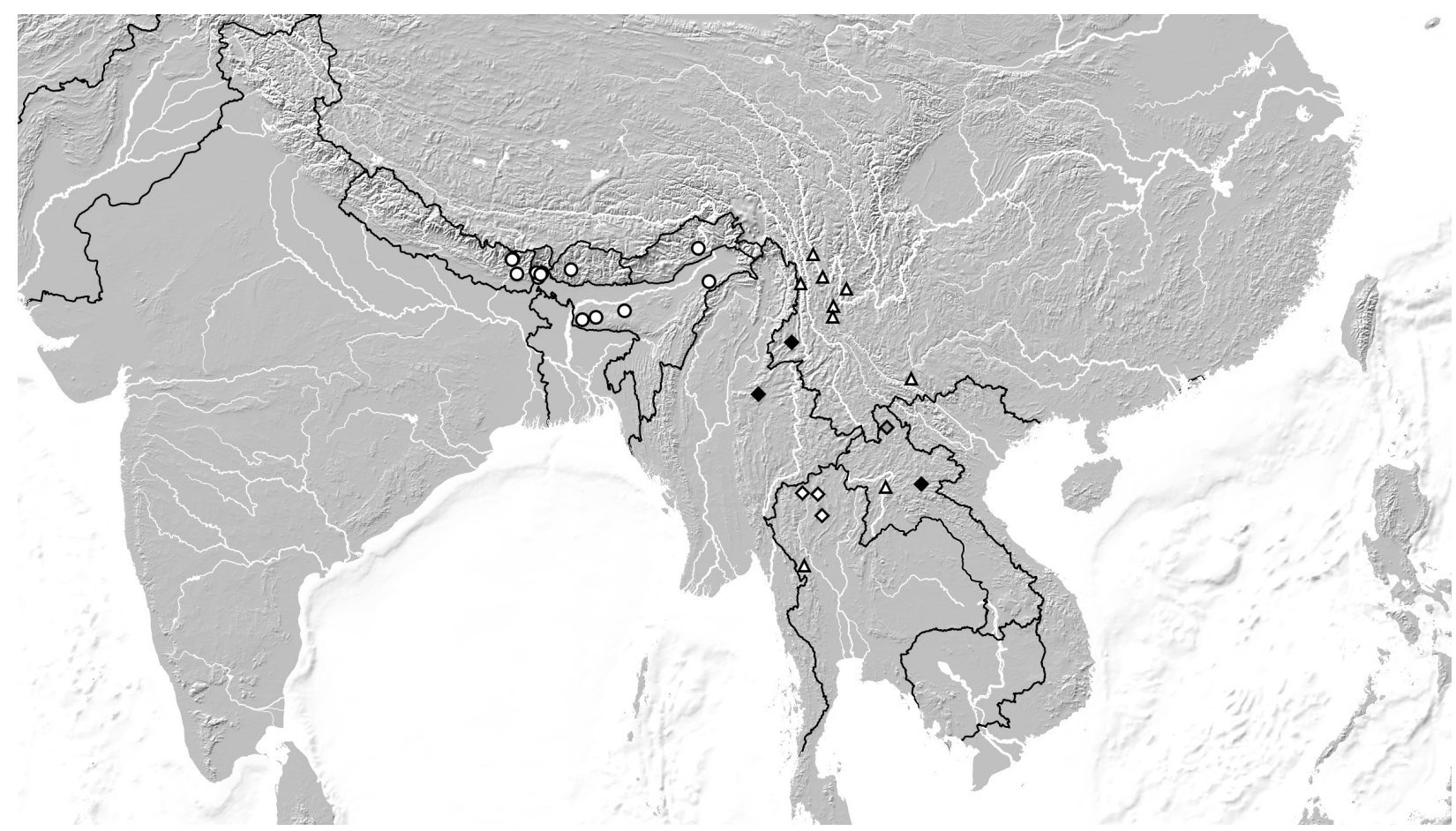

Map 5: Distributions of N. brevipennis (white circles), N. praeacutus (white triangles), N. schuelkei (black and grey diamonds), and N. macer (white and grey diamonds). 
Comment: Previously, only a single female syntype from Assam and a male from Meghalaya were known (Assing 2011a, 2013). The currently known distribution is illustrated in Map 4.

The coloration is subject to pronounced variation. The pronotum and the elytra are pale-reddish and strongly contrasting with the black head in the material from most localities. The specimens from two localities in the Meghalayan Khasi Hills (Mawsynram-Balat; Pynursla), however, have the elytra brown to dark-brown and the pronotum dark-brown to blackish, of similar coloration as the head. Some of the above specimens are teneral.

\section{Neosclerus praeacutus Assing, 2011 (Map 5)}

Material examined: China: $1 \sigma^{\star}$ [teneral], Yunnan,

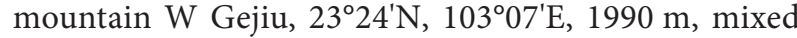
forest, litter and various debris sifted, 23.VIII.2014, leg. Schülke (cSch).

Comment: Neosclerus praeacutus has been recorded from Yunnan, Thailand, and doubtfully also from Laos (Assing 2011a, 2011b, 2013; Map 5). The above teneral male was collected together with numerous specimens of $N$. figens spec. nov.

\section{Neosclerus barbatulus Assing, 2011 (Map 4)}

Material examined: Burma: 10 exs., Maymyo env., 700-900 m, 4.-5.III.1996, leg. Kurbatov (MHNG, cAss). Thailand: 4 exs., Chiang Mai, Doi Angkhang, $10 \mathrm{~km} \mathrm{~W}$ Fang, 920 m, 18.III.1987, leg. Schwendinger (MHNG, cAss); 2 exs., Chiang Mai, Doi Suthep, 1600 m, 4.XI.1985, leg. Burckhardt \& Löbl (MHNG, cAss); 1 ㅇ, Chiang Rai, Doi Tung, 1350 m, 30.X.1991, leg. Schwendinger (MHNG).

Comment: This species has been recorded from Thailand, Burma, Laos, and the Chinese province Yunnan (Map 4).

\section{Neosclerus schuelkei Assing, 2011 (Map 5)}

Material examined: Burma: $2 \sigma^{x} \sigma^{x}, 1+$, Shan province, Namhsan, 1600 m, litter, 18.II.1996, leg. Kurbatov (MHNG, cAss).

Comment: This species had been recorded from Laos and the Chinese province Yunnan (Assing 2011a, 2013). The above specimens represent the first record from Burma. The currently known distribution is illustrated in Map 5.

\section{Neosclerus immutatus Assing, 2011}

(Map 2)

Material examined: Malaysia: 1 , Sabah, Crocker Ra., km 60 route Kota Kinabalu - Tambunan, 1270 m, 17.V.1987, leg. Burckhardt \& Löbl (MHNG).

Comment: This species was previously known only from the type locality in northern Sumatra. A comparison of the above female with the holotype revealed no significant external differences. The distribution is illustrated in Map 2.

\section{Neosclerus khasicus spec. nov.}

(Figs 17-22, Map 6)

Type material: Holotype $0^{\star}$ : “INDIA Meghalaya, Khasi Hills 28.X.78, Mawphlang $1800 \mathrm{~m}$, Besuchet-Löbl / Holotypus ơ Neosclerus khasicus spec. nov. det. V. Assing 2015” (MHNG).

Paratypes: 33 exs. [partly slightly teneral]: same data as holotype (MHNG, cAss); 10 exs. [partly slightly teneral]: "INDIA Meghalaya, Khasi Hills 25.X.78, Shillong 18501950 m, Besuchet-Löbl” (MHNG, cAss); 6 exs. [partly slightly teneral]: same data, but "30.X.78” (MHNG).

Etymology: The specific epithet is an adjective derived from Khasi Hills, where the species was discovered and where it is probably endemic.

Description: Body length 2.8-3.5 mm; length of forebody 1.5-1.6 $\mathrm{mm}$. Coloration: body black, with the pronotum and the elytra sometimes slightly paler; legs and antennae yellowish.

Head (Fig. 17) approximately 1.15 times as broad as long; punctation very coarse and dense, sparser and less coarse in posterior dorsal portion; interstices without microsculpture. Eyes very large, nearly extending to posterior angles of head. Antenna approximately $0.9 \mathrm{~mm}$ long.

Pronotum (Fig. 17) approximately 1.05 times as long as broad and about 0.85 times as broad as head; punctation moderately dense, slightly less coarse than that of head; interstices without microsculpture; midline broadly impunctate.

Elytra (Fig. 17) short, $0.60-0.65$ times as long as pronotum; punctation fine and dense. Hind wings completely reduced. Metatarsomere I approximately as long as the combined length of II and III, or nearly so.

Abdomen approximately as broad as, or slightly broader than elytra; punctation fine, dense on anterior tergites, gradually becoming less dense towards posterior tergites; interstices with shallow microsculpture; posterior margin of tergite VII without palisade fringe.

$o^{*}$ : sternite VII (Fig. 18) weakly transverse, approximately 1.1 times as broad as long, posteriorly with pronounced median excision, with small impression of triangular shape anterior to this excision, and with a pair of clusters 


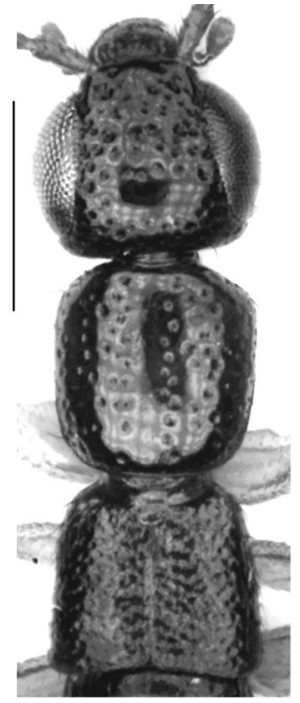

17

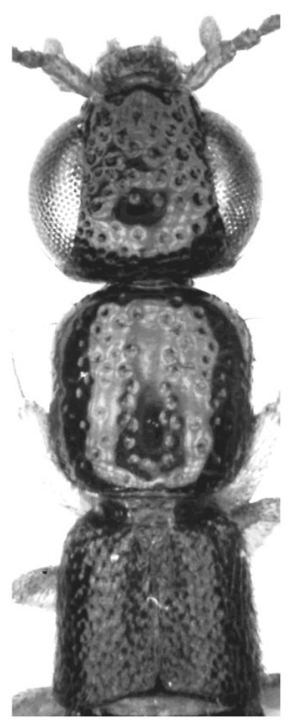

23

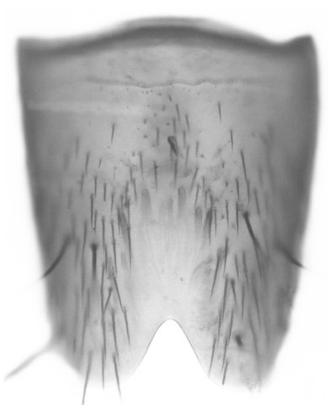

19

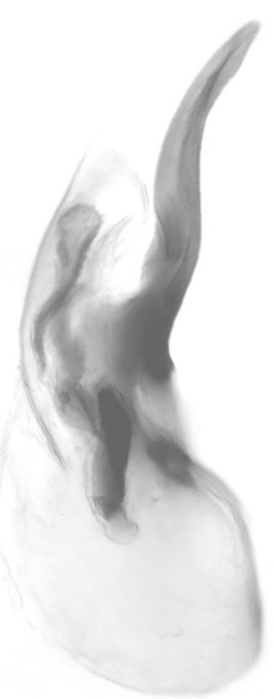

20

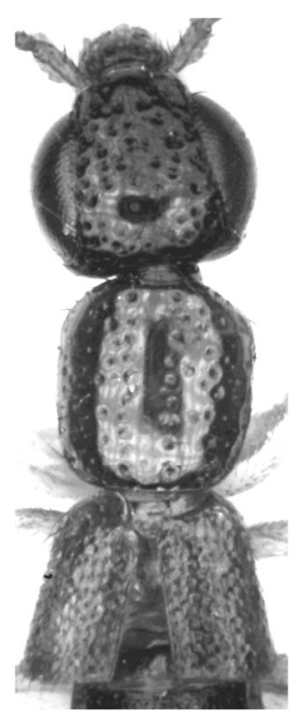

28

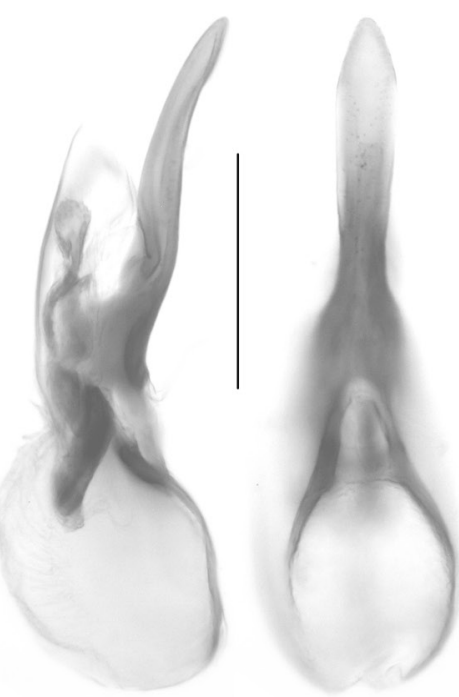

22
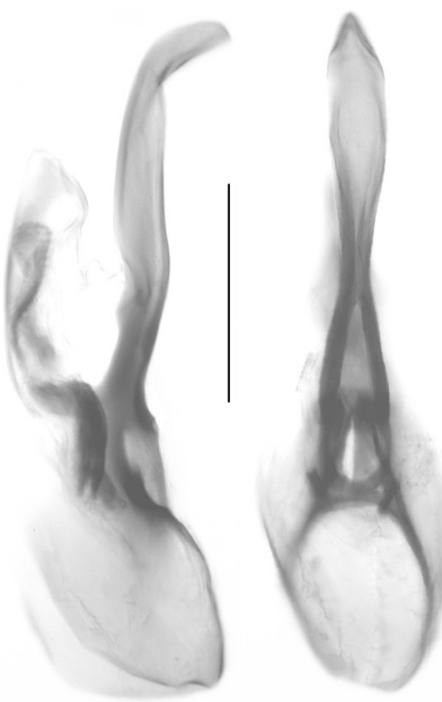

26

27

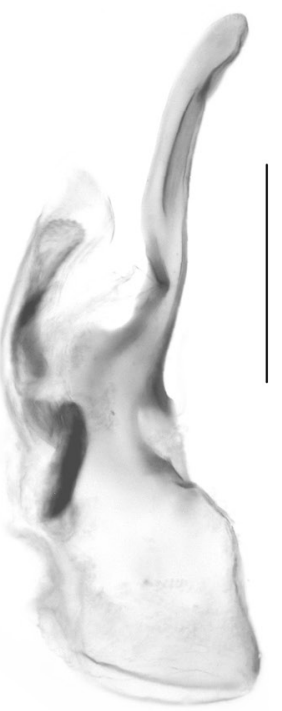

31

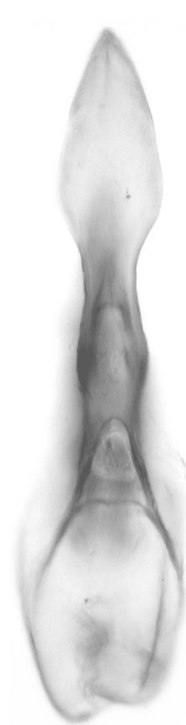

32

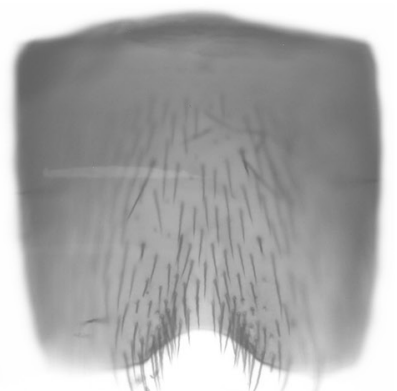

18

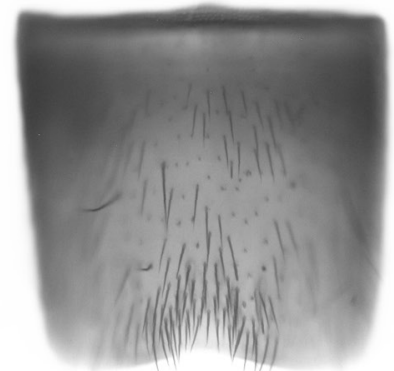

24

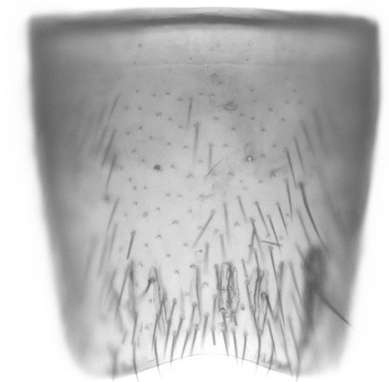

29

Figs 17-32: Neosclerus khasicus spec. nov. (17-22), N. fractus spec. nov. (23-27), and N. sagittatus spec. nov. (28-32): forebody (17, 23, 28); male sternite VII $(18,24,29)$; male sternite VIII $(19,25,30)$; aedeagus in lateral and in ventral view $(20-22,26-27,31-32)$. Scale bars: 17, 23, 28: $0.5 \mathrm{~mm}$; 16-22, 24-27, 29-32: $0.2 \mathrm{~mm}$. 
of long black setae; sternite VIII (Fig. 10) weakly oblong, posterior portion extensively impressed and without pubescence, anteriorly with a median cluster of short setae, posterior excision of triangular shape, its depth approximately one-sixth the length of sternite; aedeagus (Figs 20-22) $0.55-0.58 \mathrm{~mm}$ long; ventral process long and slender, bisinuate in lateral view, and apically moderately acute.

Comparative notes: Neosclerus khasicus is readily distinguished from all other described species recorded from India by the conspicuously short elytra, the completely reduced hind wings, and the absence of a palisade fringe at the posterior margin of the abdominal tergite VII alone. Micropterous Neosclerus species were previously known only from South China and Taiwan. For characters distinguishing $N$. khasicus from the similarly micropterous and geographically close $N$. fractus and N. sagittatus see the descriptions and comparative notes in the two following sections.

Distribution and natural history: The known distribution is confined to two localities in the Khasi Hills in Meghalaya, Northeast India (Map 6). The altitudes range from 1800 to $1950 \mathrm{~m}$. Some of the paratypes are more or less distinctly teneral.

\section{Neosclerus fractus spec. nov.}

(Figs 23-27, Map 6)

Type material: Holotype $\sigma^{\star}:$ "INDIA Meghalaya, Khasi Hills 1700 m, Cherrapunjee, 26.X.78, Besuchet-Löbl / Holotypus ot Neosclerus fractus spec. nov. det. V. Assing 2015” (MHNG).

Paratype + : "INDIA Meghalaya, Khasi Hills 26.X.78, ss/ Cherrapunjee, 1200 m, Besuchet Löbl” (cAss).

Etymology: The specific epithet is the past participle of the Latin verb frangere (to break, to bend) and alludes to the shape of the ventral process of the aedeagus in lateral view.

Description: Body length 3.5-3.7 mm; length of forebody 1.7-1.8 mm. Other external characters (Fig. 23) as in N. khasicus.

$\sigma^{7}$ : sternite VII (Fig. 24) moderately transverse, approximately 1.15 times as broad as long, posteriorly with shallow median impression and with a cluster of dense brownish setae, posterior margin broadly concave; sternite VIII (Fig. 25) distinctly oblong, approximately 1.2 times as long as broad, posterior portion extensively impressed and without pubescence, anteriorly with a median cluster of short setae, posterior excision of triangular shape, its depth approximately one-fifth the length of sternite; aedeagus (Figs 26-27) $0.65 \mathrm{~mm}$ long; ventral process long and slender, subapically strongly bent in lateral view.

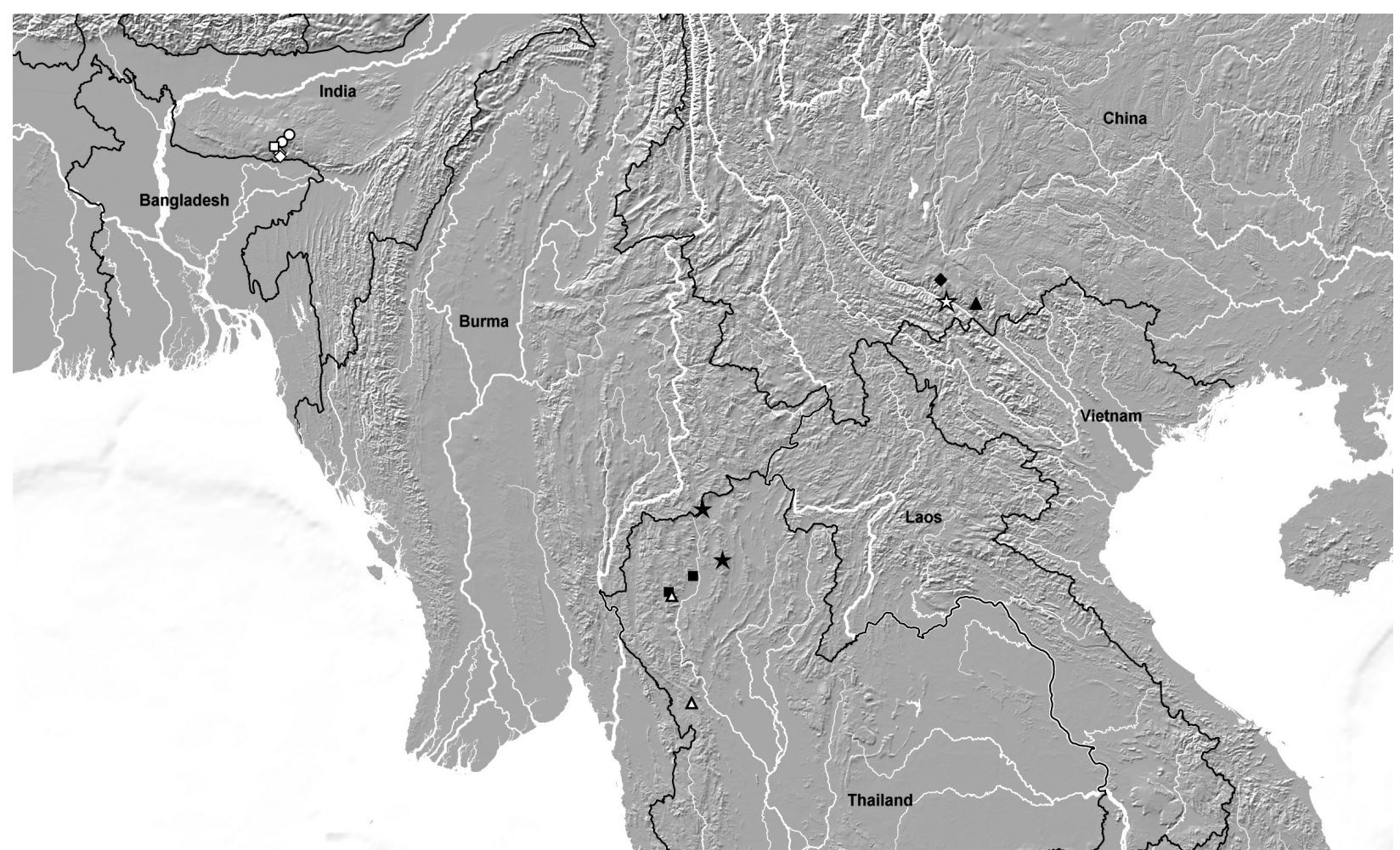

Map 6: Distributions of N. khasicus (white circles), N. sagittatus (white square), N. fractus (white diamonds), N. figens (black diamond), N. trisinuatus (white star), N. daweianus (black triangle), N. semicalvus (black stars), N. rougemonti (black squares), and $N$. biangulatus (white triangles). 
Comparative notes: Based on the male primary and sexual characters, as well as on the practically identical external characters, $N$. fractus is closely allied to $N$. khasicus, from which it differs by slightly greater body size, the more transverse male sternite VII without a pronounced median excision posteriorly and with different chaetotaxy, the more oblong male sternite VIII with a deeper posterior excision, and by the larger aedeagus with a subapically strongly bent ventral process.

Distribution and natural history: The type specimens were collected in two localities near Cherrapunjee in the Khasi Hills, Meghalaya (Map 6), at altitudes of 1200 and $1700 \mathrm{~m}$.

\section{Neosclerus sagittatus spec. nov. (Figs 28-32, Map 6)}

Type material: Holotype $\sigma^{*}$ : "INDIA Meghalaya, Khasi Hills 27.X.78, Weiloi 1700 m, Besuchet-Löbl / Holotypus o Neosclerus sagittatus spec. nov. det. V. Assing 2015" (MHNG).

Etymology: The specific epithet is an adjective derived from the Latin noun sagitta (arrow) and alludes to the shape of the ventral process of the aedeagus in ventral view.

Description: Body length $3.1 \mathrm{~mm}$; length of forebody $1.65 \mathrm{~mm}$. External characters (Fig. 28) as in N. khasicus. $0^{7}$ : sternite VII (Fig. 29) very weakly transverse, approximately 1.05 times as broad as long, posterior margin broadly concave, pubescence not distinctly modified; sternite VIII (Fig. 30) distinctly oblong, approximately 1.2 times as long as broad, posterior portion extensively impressed and without pubescence, anteriorly with a median cluster of short setae, posterior excision of triangular shape, its depth approximately one-sixth the length of sternite; aedeagus (Figs 31-32) $0.63 \mathrm{~mm}$ long; ventral process long and slender in lateral view, distinctly dilated subapically in ventral view.

Comparative notes: Based on the male primary and sexual characters, as well as on the practically identical external characters, N. sagittatus is closely allied to the geographically close $N$. fractus and $N$. khasicus. It differs from both species by the less transverse male sternite VII with unmodified pubescence and by the distinctive shape of the ventral process of the aedeagus.

Distribution and natural history: The type locality is situated in the Khasi Hills in Meghalaya, Northeast India (Map 6), at an altitude of $1700 \mathrm{~m}$.

\section{Neosclerus discolor spec. nov.}

(Figs 33-39, Map 4)

Type material: Holotype $\sigma^{\star}:$ "BURMA Chin prov., env. Saw 900-1500 m, 27.-28.02.1996, leg. S. Kurbatov / Holotypus ơ Neosclerus discolor spec. nov. det. V. Assing 2015" (MHNG).

Paratypes: $30^{\top} o^{-1}$ : same data as holotype (MHNG, cAss); 6 exs.: "THAILAND: Mae Hong Son, Tom Lok, $8 \mathrm{~km}$ N Mae Lang, 700 m, 11, 13.XI.1985, Burckhardt-Löbl” (MHNG, cAss); 1 : : “THAILAND 24.II.87, prov. Chiang Mai, Doi Inthanon 1080 m, P. Schwendinger” (MHNG).

Etymology: The specific epithet (Latin, adjective: colourful) alludes to the distinctive coloration.

Description: Body length 2.9-3.7 mm; length of forebody $1.6-1.9 \mathrm{~mm}$. Coloration: head black; pronotum pale-reddish; elytra yellowish, with the sutural portion often more or less distinctly and more or less extensively infuscate; abdomen reddish, with the apex often more or less distinctly darker; legs and antennae yellowish.

Head (Fig. 33) approximately 1.25 times as broad as long; punctation very coarse and dense, sparser in posterior dorsal portion; interstices without microsculpture. Eyes very large, nearly extending to posterior angles of head. Antenna approximately $1.0 \mathrm{~mm}$ long.

Pronotum (Fig. 33) approximately as broad as long and 0.8 times as broad as head; punctation dense, similar to that of head; interstices without microsculpture; midline with narrow impunctate band of variable length.

Elytra (Fig. 33) of rather variable length, 1.02-1.15 times as long as pronotum; punctation rather fine and very dense. Hind wings present. Metatarsomere I approximately as long as the combined length of II and III.

Abdomen noticeably narrower than elytra; punctation extremely fine and dense; interstices with distinct microsculpture; posterior margin of tergite VII with palisade fringe.

$\sigma^{\star}$ : sternite VII (Figs 34-35) moderately transverse, 1.15-1.20 times as broad as long, and with pubescence of variable density, posterior margin with, rarely without, concavity of variable depth in the middle, near this concavity with a cluster of short dark setae; sternite VIII (Figs 36-37) as broad as long or weakly oblong, anteriorly without process or elevation, but with sparse cluster of setae, postero-median portion depressed and largely without pubescence, posterior excision broadly $\mathrm{V}$-shaped and approximately 0.2 times as deep as length of sternite; aedeagus (Figs 38-39) 0.48-0.54 mm long, with ventral process and internal structures of distinctive shapes.

Intraspecific variation: This species is subject to rather pronounced variation not only of external characters, such as the coloration (particularly of the elytra and the abdominal apex) and the length of the elytra, but also of the chaetotaxy (pubescence moderately sparse to rather dense) and shape of the male sternite VII (posterior 


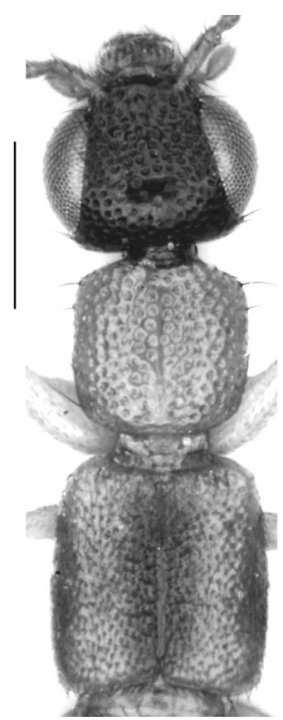

33

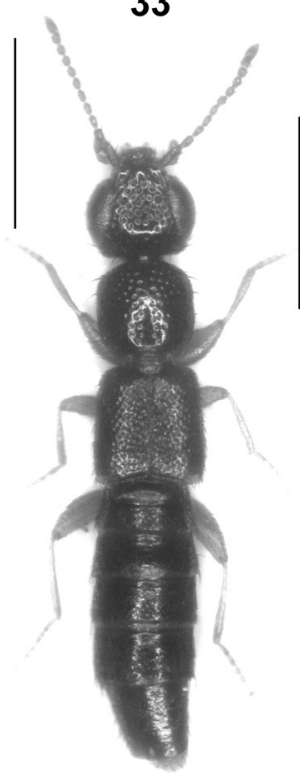

40

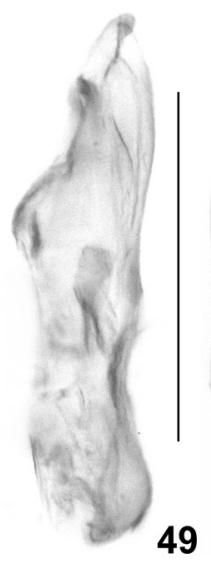

49

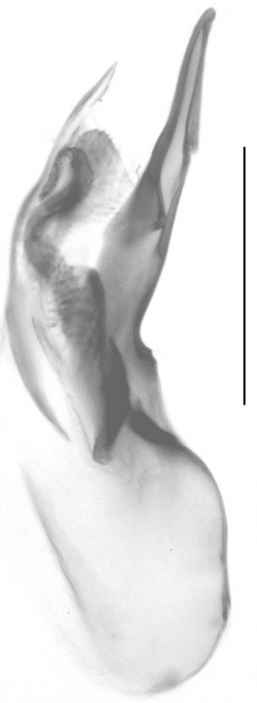

38

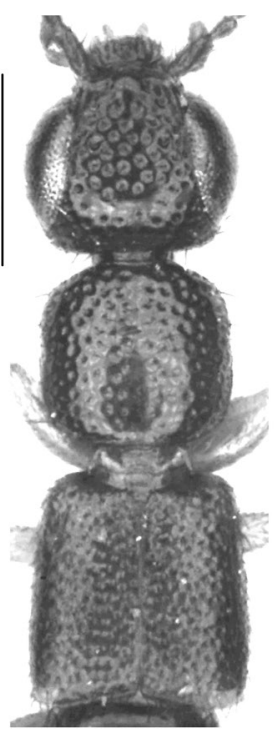

41

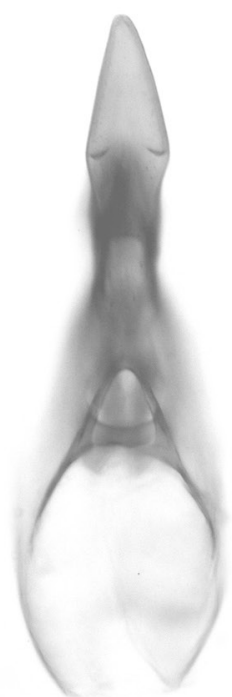

39

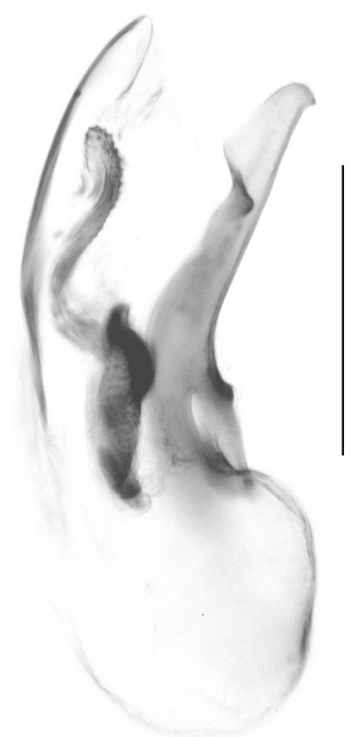

45

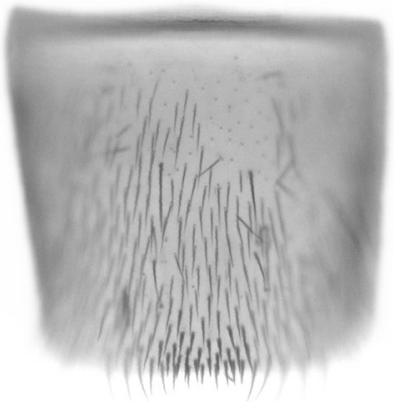

34

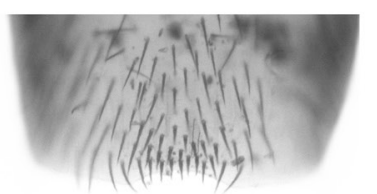

35

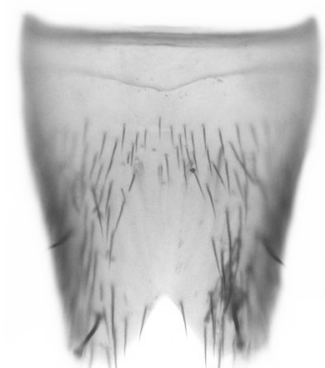

36

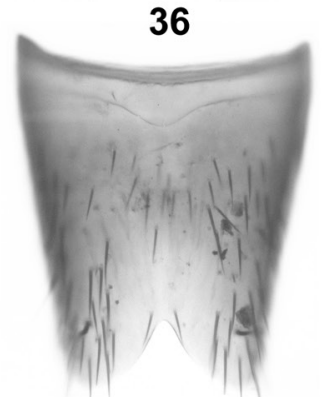

37

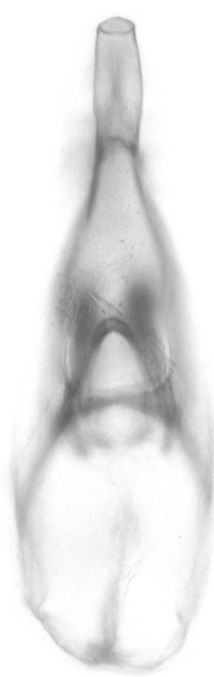

46

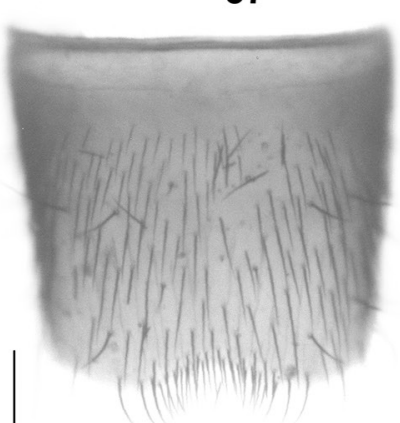

42

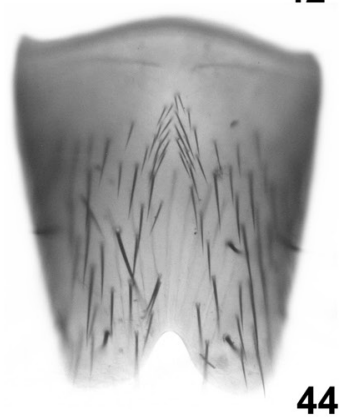

44

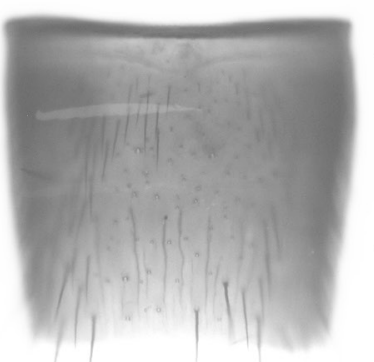

47

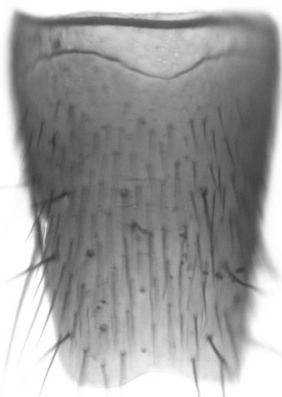

48

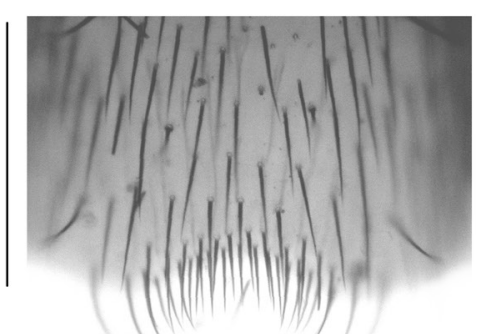

43

Figs 33-50: Neosclerus discolor spec. nov. (33-39; 33-34, 36, 38-39: Burma; 35, 37: Thailand), N. trisinuatus spec. nov. (40-46), and N. granulicollis Cameron (47-50): forebody (33, 41); male sternite VII $(34,42,47)$; male sternite VIII $(36-37,44,48)$; aedeagus in lateral and in ventral view $(38-39,45-46,49-50)$; posterior portion of male sternite VII $(35,43)$; habitus $(40)$. Scale bars: 40 : $1.0 \mathrm{~mm} ; 33,41: 0.5 \mathrm{~mm} ; 34-39,42-50: 0.2 \mathrm{~mm}$. 
concavity more or less pronounced, in one male even absent; Figs 34-35), the density of the pubescence of the male sternite VIII (Figs 36-37), and also the shape of the ventral process in ventral view (basally more or less distinctly narrowed).

Comparative notes: Using the key in Assing (2011a), $N$. discolor would key out together with $N$. assamensis, a species not only of similar coloration and general appearance, but also closely related, as can be inferred from the similar modifications of the male secondary sexual characters and the similar morphology of the aedeagus (shapes of ventral process and of internal structures). The new species differs from $N$. assamensis particularly by the coloration of the elytra ( $N$. assamensis: elytra uniformly yellowish) and by the shape of the ventral process of the aedeagus. For illustrations of N. assamensis see Assing (2011a, b).

Distribution and natural history: The known distribution is confined to three localities, one in Burma and two in Thailand (Map 4). The specimens were collected at altitudes between 700 and $1500 \mathrm{~m}$.

\section{Neosclerus trisinuatus spec. nov. (Figs 40-46, Map 6)}

Type material: Holotype $\sigma^{*}$ : "CHINA [15] - Yunnan, valley $S$ Gejiu, road margin, $23^{\circ} 08^{\prime} 38^{\prime \prime} \mathrm{N}, 103^{\circ} 11^{\prime} 42^{\prime \prime} \mathrm{E}$, 1010 m, 21.VIII.2014, V. Assing / Holotypus ơ Neosclerus trisinuatus spec. nov. det. V. Assing 2015” (cAss).

Paratype: 1 : : same data as holotype, but leg. Schülke (cSch).

Etymology: The specific epithet (Latin, adjective) alludes to the shape of the internal structures of the aedeagus in lateral view.

Description: Body length 2.8-3.3 mm; length of forebody $1.7 \mathrm{~mm}$. Habitus as in Fig. 40. Coloration: head, pronotum, and abdomen blackish; elytra blackish-brown with the posterior margin and the humeral portions diffusely paler; legs yellowish; antennae reddish.

Head (Fig. 41) approximately 1.15 times as broad as long; punctation very coarse and dense, somewhat sparser and slightly less coarse in posterior dorsal portion; interstices without microsculpture, in median dorsal portion much narrower than diameter of punctures. Eyes very large, nearly extending to posterior angles of head. Antenna approximately $0.9 \mathrm{~mm}$ long.

Pronotum (Fig. 41) approximately 1.05 times as broad as long and 0.9 times as broad as head; punctation dense and slightly less coarse than that of head; interstices without microsculpture.

Elytra (Fig. 41) approximately as long as pronotum; punctation moderately coarse and very dense. Hind wings probably present. Metatarsomere I approximately as long as the combined length of II and III.
Abdomen noticeably narrower than elytra; punctation extremely fine, slightly denser on anterior than on posterior tergites; microsculpture of tergites III-VI extremely shallow (visible only at high magnification), that of tergite VII more distinct; posterior margin of tergite VII with palisade fringe.

$\sigma^{\star}$ : sternite VII (Figs 42-43) weakly transverse, approximately 1.1 times as broad as long, and with dense pubescence, posterior margin weakly concave in the middle, near this concavity with a dense cluster of long black setae; sternite VIII (Fig. 44) oblong, approximately 1.1 times as long as broad, anteriorly without process or elevation, but with sparse cluster of short black setae, median portion not distinctly modified, posterior excision $\mathrm{V}$-shaped and approximately 0.15 times as deep as length of sternite; aedeagus (Figs 45-46) $0.46 \mathrm{~mm}$ long, with ventral process and internal structures of distinctive shapes.

Comparative notes: Based on the external and male sexual characters, $N$. trisinuatus is related to $N$. brevipennis (CAMERON, 1943) and allied species. Regarding the shape and chaetotaxy of the male sternite VII (posterior margin concave, near this concavity with cluster of long setae), the shape of the male sternite VIII (anteriorly without process or elevation), and the morphology of the aedeagus (shapes of ventral process and internal structures), the new species is most similar to N. rimatus Assing, 2011 and N. incisus Assing, 2011, both known only from the Chinese province Guangxi. It is distinguished from both by the longer elytra, the larger and denser posterior cluster of longer setae on the male sternite VIII, the presence of an anterior cluster of short setae and the presence of setae in the median portion of the male sternite VIII, as well as by the shapes of the ventral process and the internal structures of the aedeagus, from $N$. incisus additionally by the much broader posterior excision of the male sternite VIII. For illustrations of N. rimatus and N. incisus see Assing (2011a).

Distribution and natural history: The type locality is situated to the south of Gejiu in southeastern Yunnan, South China, not far from the border with Vietnam (Map 6). The specimens were sifted from litter and soil at a road margin with sparse vegetation at an altitude of $1010 \mathrm{~m}$

\section{Neosclerus figens spec. nov.}

(Figs 51-58, Map 6)

Type material: Holotype $o^{\star}$ : "CHINA [20] - Yunnan, mt. W Gejiu, mixed forest, 2324'13"N, 10307'28"E, 1990 m, 23.VIII.2014, V. Assing / Holotypus o Neosclerus figens spec. nov. det. V. Assing 2015” (cAss).

Paratypes: $3 \sigma^{\top} \sigma^{\top}, 15$ 우 우 [partly teneral]: same data as holotype (cAss, MNHUB); $10^{x}, 5$ ㅇ ㅇ: same data, but leg. Schülke (cSch); 2 우: “CHINA [20a] - Yunnan, 


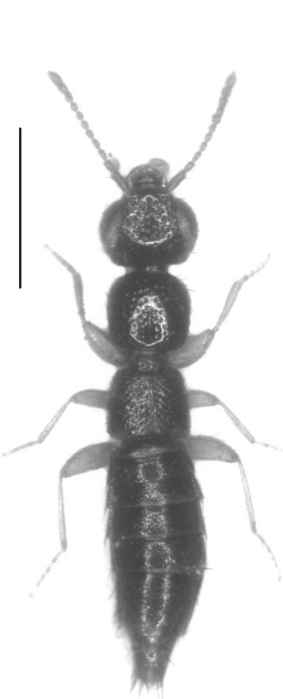

51

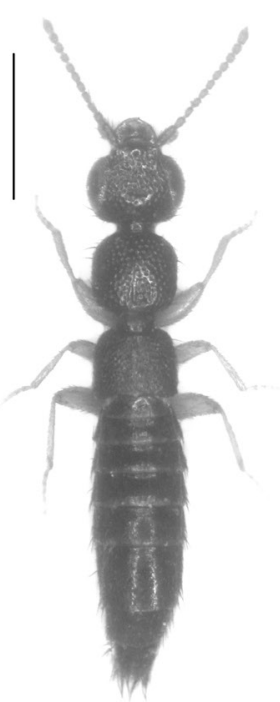

59

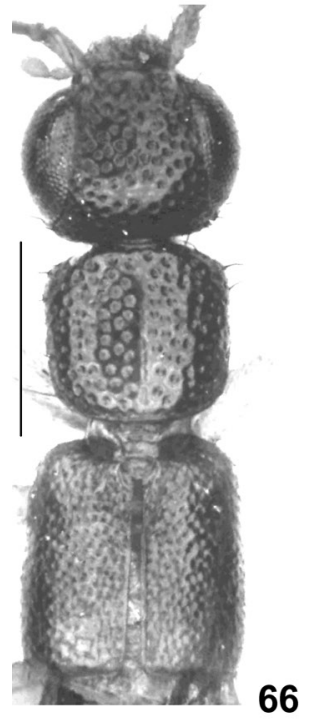

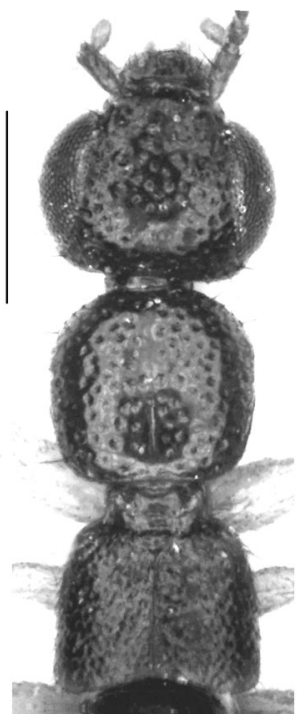

52

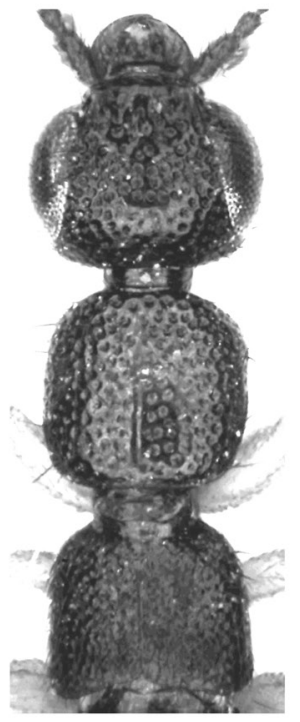

60

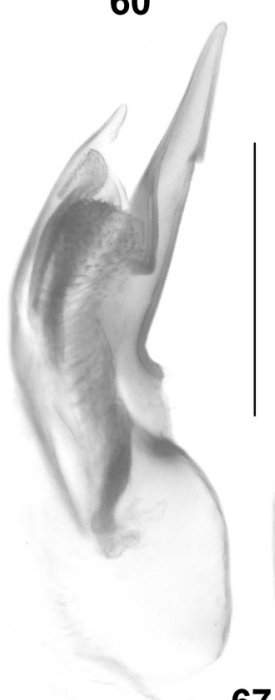

67

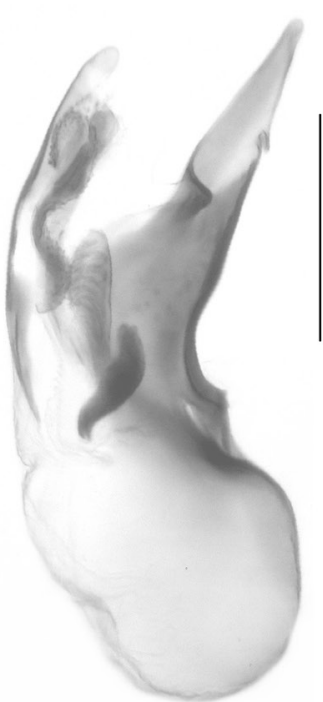

57

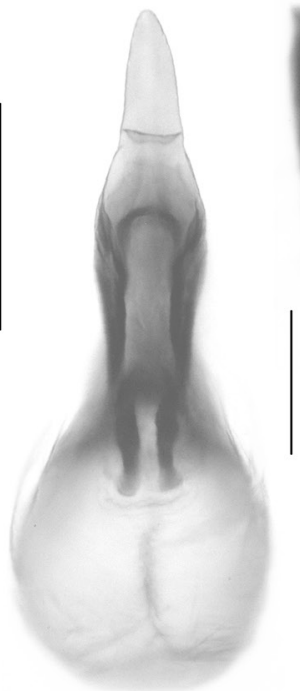

58

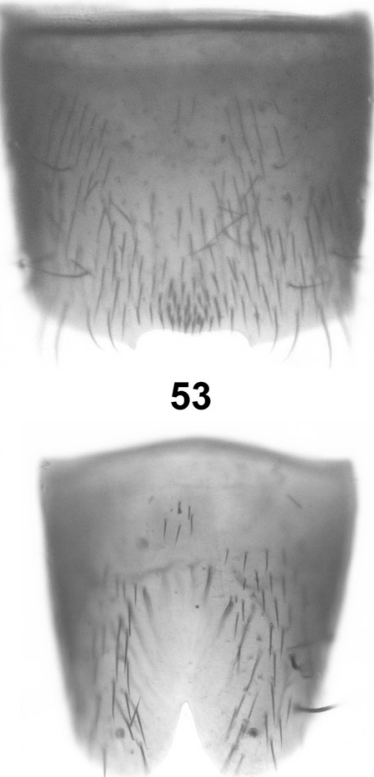

55

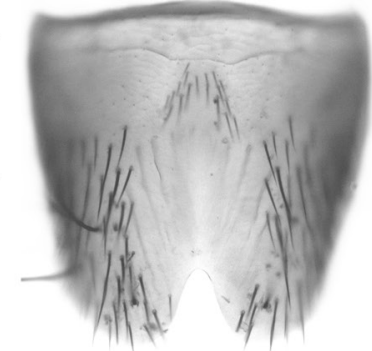

62
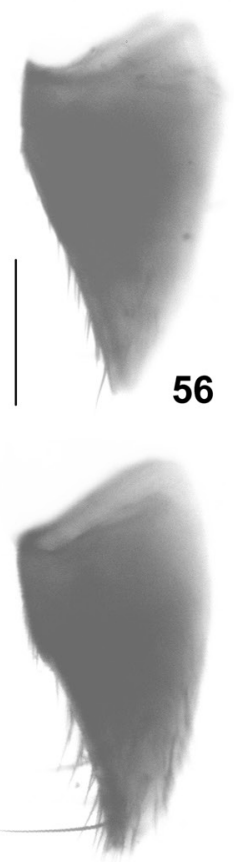

63

Figs 51-68: Neosclerus figens spec. nov. (51-58), N. daweianus spec. nov. (59-65), and N. biangulatus spec. nov. (66-68): habitus $(51,59)$; forebody $(52,60,66)$; male sternite VII $(53)$; postero-median portion of male sternite VII $(54,61)$; male sternite VIII $(55,62)$; male sternite VIII in lateral view $(56,63)$; aedeagus in lateral and in ventral view $(57-58,64-65,67-68)$. Scale bars: 51 , 59: $1.0 \mathrm{~mm}$; 52, 60, 66: $0.5 \mathrm{~mm}$; 53-58, 61-65, 67-68: $0.2 \mathrm{~mm}$. 
mt. W Gejiu, mixed forest, $23^{\circ} 24^{\prime} 13^{\prime \prime N}, 103^{\circ} 07^{\prime} 28^{\prime \prime} \mathrm{E}$, 1990 m, 24.VIII.2014, V. Assing" (cAss, MNHUB); 4 우 우: same data, but leg. Schülke (cSch); 2 ๙ $^{\star}, 3$ ㅇ ㅇ [partly teneral]: "CHINA [20b] - Yunnan, mt. W Gejiu, mixed forest, $23^{\circ} 24^{\prime} 13^{\prime \prime} \mathrm{N}, 103^{\circ} 07^{\prime} 28^{\prime \prime} \mathrm{E}, 1990 \mathrm{~m}, 25$. VIII.2014, V. Assing" (cAss, MNHUB); 7 i ㅇ: same data, but leg. Schülke (cSch).

Etymology: The specific epithet is the present participle of the Latin verb figere (to stab, to pierce) and alludes to the long, straight, and apically very acute ventral process of the aedeagus.

Description: Body length 2.8-3.5 mm; length of forebody $1.5-1.7 \mathrm{~mm}$. Habitus as in Fig. 51. Coloration: head and abdomen blackish; pronotum and elytra dark-brown to blackish brown, with the posterior margins and the humeral portions of the elytra indistinctly and diffusely paler; legs yellowish; antennae reddish.

Head (Fig. 52) 1.20-1.25 times as broad as long; punctation moderately coarse and moderately dense, rather sparse in posterior dorsal portion; interstices without microsculpture, on frons and between eyes on average approximately as broad as diameter of punctures. Eyes very large, nearly extending to posterior angles of head. Antenna 0.8-0.9 mm long.

Pronotum (Fig. 52) 1.01-1.04 times as broad as long and approximately 0.85 times as broad as head; punctation similar to that of head; interstices without microsculpture.

Elytra (Fig. 52) short, $0.60-0.65$ times as long as pronotum; punctation moderately fine and dense. Hind wings completely reduced. Metatarsomere I approximately as long as the combined length of II and III.

Abdomen broader than elytra; punctation very fine; microsculpture of tergites III-VI extremely shallow, that of tergite VII more distinct; posterior margin of tergite VII without palisade fringe.

$o^{\top}$ : sternite VII (Figs 53-54) transverse, approximately 1.15 times as broad as long, and with dense pubescence, posterior margin in the middle with sharply delimited concavity, anterior to this concavity with distinct dense cluster of strongly modified short and stout black setae; sternite VIII (Figs 55-56) indistinctly oblong, posteromedian portion extensively depressed and without pubescence, near anterior margin with few black setae in the middle, without process or elevation, posterior excision narrowly $\mathrm{V}$-shaped and $0.20-0.25$ times as deep as sternite; aedeagus (Figs 57-58) approximately $0.6 \mathrm{~mm}$ long; ventral process straight, gradually tapering apicad, and apically acute; internal sac with a pair of distinctly sclerotized basal structures and a pair of dark and long membranous structures.

Comparative notes: The male sexual characters of $N$. figens are similar to those of $N$. brevipennis, from which the new species differs by shorter elytra ( $N$. brevipennis: elytra at least 0.85 times as long as pronotum), the completely reduced hind wings, the absence of a palisade fringe at the posterior margin of tergite VII, the modifications of the male sternite VII (N. brevipennis: posterior margin weakly concave, but without pronounced median concavity; posterior cluster with weakly modified setae), the less oblong male sternite VIII with a narrower posterior excision, and by the morphology of the aedeagus (ventral process ventrally more or less distinctly angled at apical third and less acute in lateral view, broader in ventral view; internal structures of different shapes). For illustrations of the external and male sexual characters of N. brevipennis see Assing (2011a). From the syntopic $N$. praeacutus, $N$. figens is easily distinguished by the much shorter elytra, the distinctly less coarse and less dense punctation of the head and pronotum, and the absence of a palisade fringe at the posterior margin of tergite VII alone.

Distribution and natural history: The type locality is situated on a mountain to the west of Gejiu in southeastern Yunnan, South China (Map 6). The specimens were sifted from litter and various debris in, and at the margin of, a mixed forest at an altitude of nearly $2000 \mathrm{~m}$, together with $N$. praeacutus. Several of the paratypes are teneral. The sex ratio is remarkably biased: only seven (16\%) in a total of 43 specimens are males.

\section{Neosclerus daweianus spec. nov. (Figs 59-65, Map 6)}

Type material: Holotype $o^{\top}$ : "CHINA [21] - Yunnan, NNE Pingbian, broad-leaved for., $23^{\circ} 00^{\prime} 39^{\prime \prime} \mathrm{N}, 103^{\circ} 42^{\prime} 10^{\prime \prime} \mathrm{E}$, 1500 m, 26.VIII.2014, V. Assing / Holotypus ơ Neosclerus daweianus spec. nov. det. V. Assing 2015" (cAss).

Paratypes: $4 \sigma^{\top} \sigma^{\star}, 7$ 우 [partly teneral]: same data as holotype (cAss, MNHUB); 4 o $^{\star} 0^{\star}, 15$ ㅇ ㅇ [partly teneral]: same data, but leg. Schülke (cSch, cAss).

Etymology: The specific epithet (adjective) is derived from the name of the mountain, where the type locality is situated.

Description: Body length 3.3-4.0 mm; length of forebody $1.7-1.9 \mathrm{~mm}$. Habitus as in Fig. 59. Coloration: head blackish; pronotum, elytra, and abdomen blackish-brown to blackish, with the elytra sometimes slightly paler; legs yellowish; antennae reddish.

Head (Fig. 60) 1.20-1.25 times as broad as long; punctation coarse and very dense, only slightly less dense in posterior dorsal portion; interstices without microsculpture in anterior dorsal portion and with shallow microsculpture in posterior dorsal portion, on average much narrower than diameter of punctures even in posterior dorsal portion. Eyes very large, nearly extending to posterior angles of head. Antenna approximately $1.0 \mathrm{~mm}$ long. 
Pronotum (Fig. 60) 1.02-1.04 times as broad as long and approximately 0.85 times as broad as head; punctation very dense and coarse, similar to that of head; interstices without microsculpture.

Elytra (Fig. 60) short, $0.60-0.65$ times as long as pronotum; punctation extremely dense, weakly defined, and rather coarse, rendering the surface matt or nearly so. Hind wings completely reduced. Metatarsomere I usually slightly shorter than the combined length of II and III. Abdomen broader than elytra; punctation very fine and rather dense; interstices with distinct transverse microsculpture; posterior margin of tergite VII without palisade fringe.

$\sigma^{*}$ : sternite VII (Fig. 61) transverse, approximately 1.15 times as broad as long, and with dense pubescence, posterior margin in the middle with broad and very shallow, but distinctly delimited concavity, anterior to this concavity with distinct cluster of modified short and stout black setae; sternite VIII (Figs 62-63) approximately as long as broad, postero-median portion extensively depressed and without pubescence, near anterior margin with a cluster of fine black setae in the middle, without process or elevation, posterior excision narrowly $\mathrm{V}$-shaped and approximately 0.2 times as deep as sternite; aedeagus (Figs 64-65) approximately $0.75 \mathrm{~mm}$ long; ventral process straight and apically very acute; internal sac with a pair of short sclerotized basal spines and with dark apical structures.

Comparative notes: Regarding its external and male sexual characters, $N$. daweianus is similar to $N$. assamensis (CAMERON, 1931) from Northeast India, from which the new species differs by the darker coloration, the more transverse male sternite VII with a broader and distinctly delimited posterior concavity, the less oblong male sternite VIII with a more extensive depression, only few setae in the antero-median portion, and a much narrower posterior excision, and by an aedeagus with a longer ventral process pointing more strongly ventrad and with differently shaped internal structures. For illustrations of the external and male sexual characters of $N$. assamensis see Assing (2011a, 2013).

Distribution and natural history: The type locality is situated at the foot of the Dawei Shan near Pingbian in southeastern Yunnan, South China (Map 6). The partly teneral specimens were sifted from litter in a subtropical broad-leaved forest at an altitude of $1500 \mathrm{~m}$.

\section{Neosclerus biangulatus spec. nov.}

(Figs 66-68, 84-85, Map 6)

Type material: Holotype $\sigma^{*}$ : "THAILAND [34] - Doi Inthanon, route to Mae Wang, $18^{\circ} 35^{\prime} \mathrm{N}, 98^{\circ} 31^{\prime} \mathrm{E}, 1580 \mathrm{~m}$, 9.I.2014, leg. Ob / Holotypus ơ Neosclerus biangulatus sp. n. det. V. Assing 2015" (cAss).

Paratypes: 2 ㅇ ㅇ: same data as holotype (cAss); $10^{*}, 2$ 우 + : “THAILAND [1] - Doi Inthanon, Mae Aum, $18^{\circ} 32^{\prime} \mathrm{N}$, 9831'E, 1560 m, sifted near stream, 18.XII.2013, leg. Ob" (cAss); 1 \%: "THAILAND [37] - Doi Inthanon, Khun Huay Hang, $18^{\circ} 34^{\prime} \mathrm{N}, 98^{\circ} 31^{\prime} \mathrm{E}, 1290 \mathrm{~m}$, along stream, 11.I.2014, leg. Ob” (cAss); 1 ``, 2 우 ㅇ: “THAILAND: Taksin Maharat N. P., 1000 m 9.2.1993. Schwendinger” (MHNG, cAss).

Etymology: The specific epithet (Latin, adjective: with two angles) alludes to the shape of the posterior margin of the male sternite VII.

Description: Body length 2.7-3.0 mm; length of forebody 1.7-1.8 mm. Coloration: head and pronotum dark-brown to blackish; elytra brown with slightly and diffusely paler humeral angles and posterior margins; abdomen darkbrown to blackish-brown with paler apex; legs yellow; antennae reddish-yellow.

Head (Fig. 66) approximately 1.2 times as broad as long; punctation coarse and very dense, less dense in posterior dorsal portion; interstices without microsculpture. Eyes very large, nearly extending to posterior angles of head. Antenna approximately $0.9 \mathrm{~mm}$ long.

Pronotum (Fig. 66) 1.02-1.04 times as broad as long and $0.80-0.85$ times as broad as head; punctation dense and coarse, similar to that of head; interstices without microsculpture.

Elytra (Fig. 66) long, approximately 1.1 times as long as pronotum; punctation dense and rather fine. Hind wings fully developed. Metatarsomere I approximately as long as the combined length of II and III.

Abdomen narrower than elytra; punctation fine and moderately dense; interstices with distinct transverse microsculpture; posterior margin of tergite VII with palisade fringe.

$\sigma^{*}$ : sternite VII (Fig. 84) approximately as broad as long, and with moderately dense pubescence, in posteromedian portion with a cluster of approximately ten short setae, posterior margin with an angular projection on either side; sternite VIII (Fig. 85) weakly oblong, in posterior portion impunctate and without pubescence, except for few setae along the middle, posterior excision of triangular shape and approximately 0.15 times as deep as length of sternite; aedeagus (Figs 67-68) $0.5 \mathrm{~mm}$ long; ventral process straight, subapically dentate, and apically very acute; internal sac with dark membranous structures.

Comparative notes: The external and male sexual characters are most similar to those of $N$. rougemonti Assing, 2011 (Thailand: Doi Inthanon, Doi Suthep), from which the new species is distinguished by the denser punc- 


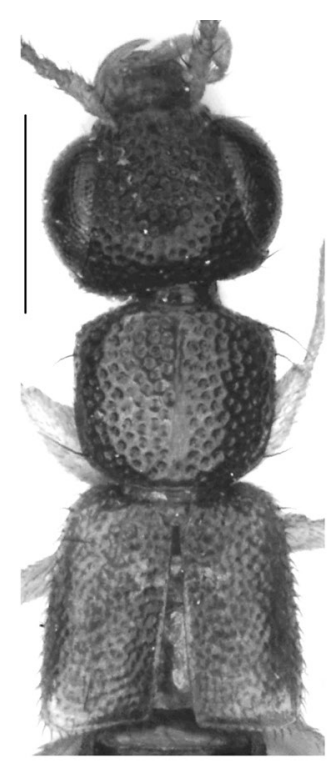

69

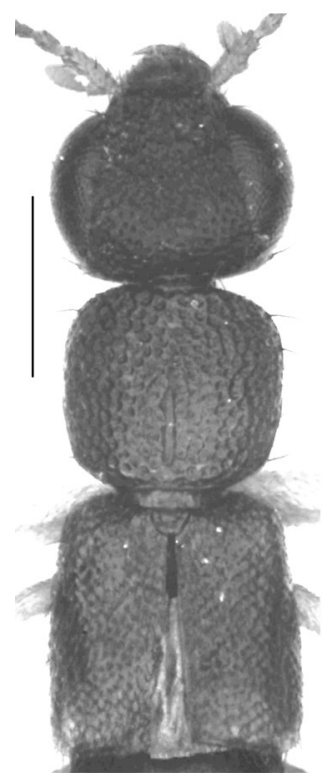

75

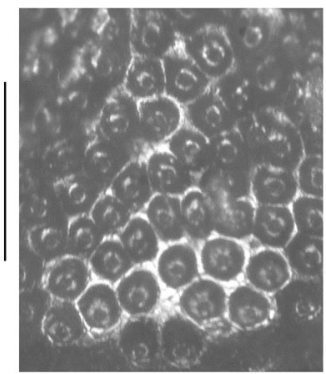

76

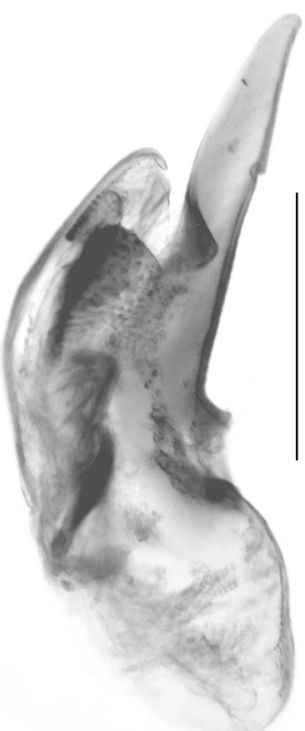

73

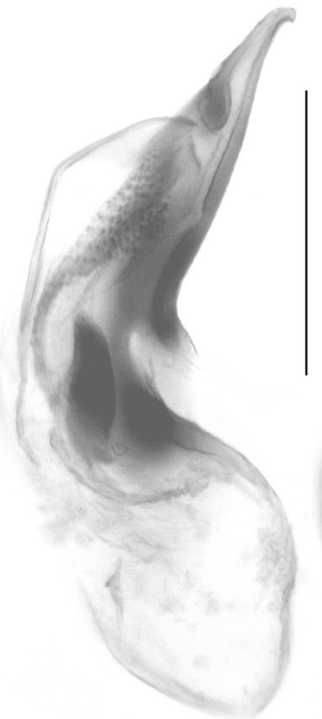

82

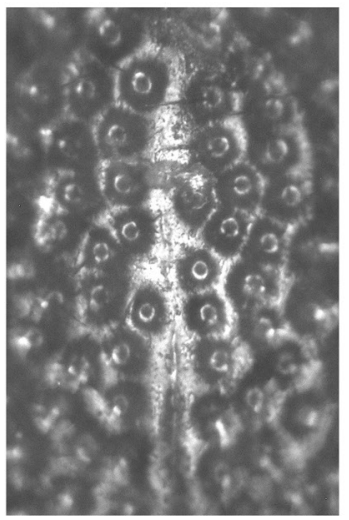

77

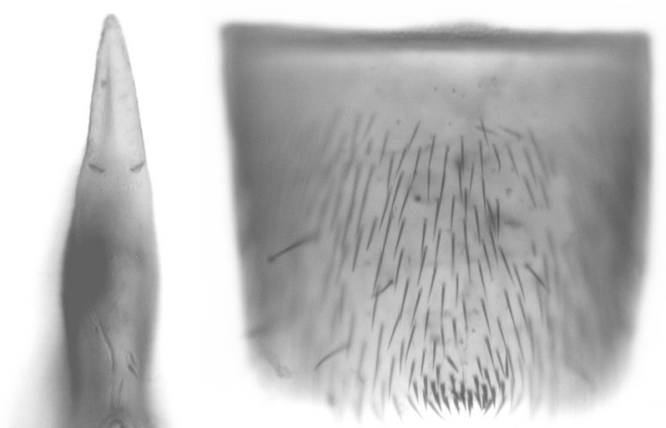

70

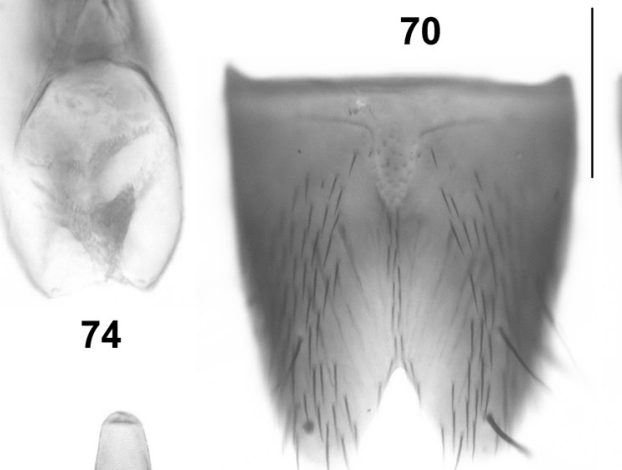

72

80

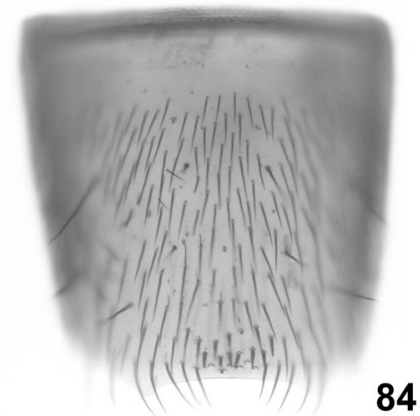

71
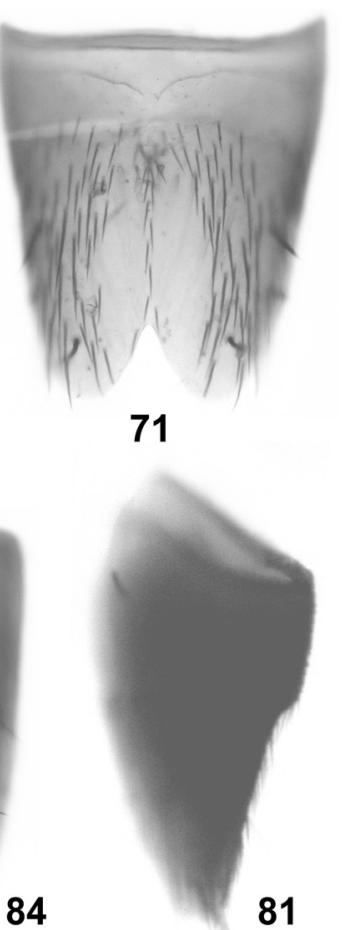

81

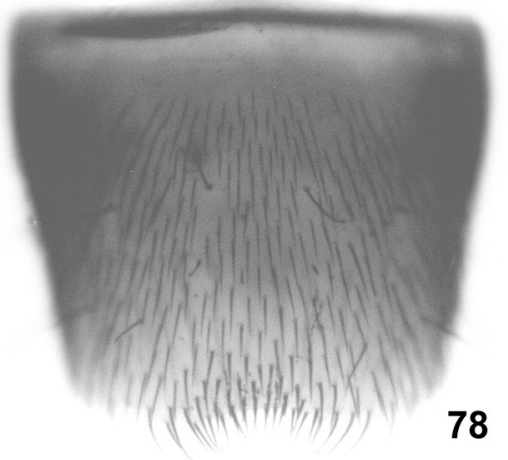

83

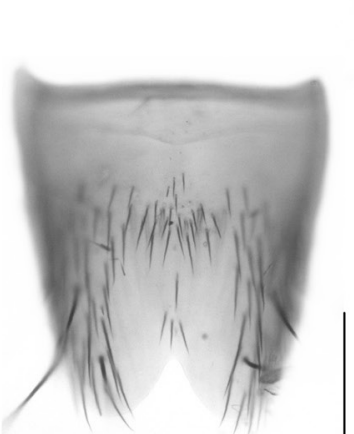

85

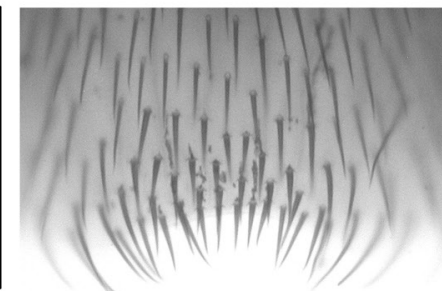

Figs 69-85: Neosclerus semicalvus spec. nov. (69-74), N. areolatus spec. nov. (75-83), and N. biangulatus spec. nov. (84-85): forebody $(69,75)$; male sternite VII $(70,78,84)$; male sternite VIII $(71,80,85)$; male sternite VIII in lateral view $(72,81)$; aedeagus in lateral and in ventral view (73-74, 82-83); median dorsal portion of head (76); median portion of pronotum (77); posteromedian portion of male sternite VII (79). Scale bars: 69, 75: $0.5 \mathrm{~mm} ; 70-74,78-85: 0.2 \mathrm{~mm}$; 76-77: 0.1 mm. 
tation of the head and pronotum, the less broad male sternite VII with fewer short setae in postero-median portion and with a pair of angular projections at its posterior margin (absent in $N$. rougemonti), a male sternite VIII with some setae along the middle in posterior portion and with a narrower posterior excision, and by the longer, more slender, and more acute apical portion of the ventral process of the aedeagus. For illustrations of N. rougemonti see Assing (2011a).

Distribution and natural history: The species is currently known from Doi Inthanon and Taksin Maharat National Park in northwestern Thailand (Map 6). The specimens were collected at altitudes between 1000 and $1580 \mathrm{~m}$, those from Doi Inthanon by sifting litter and debris along streams.

\section{Neosclerus semicalvus spec. nov. (Figs 69-74, Map 6)}

Type material: Holotype $0^{*}:$ "THAILAND: Chiang Mai, Mae Nang Kaeo [1904'N, 99²3'E], 900 m, 54 km NE Chiang Mai, Burckhardt-Löbl, 3.XI.85 / Holotypus o* Neosclerus semicalvus spec. nov. det. V. Assing 2015" (MHNG).

Paratypes: 6 exs.: same data as holotype (MHNG, cAss); 1 o $^{*}$ :THAILAND: Chiang Mai, Doi Angkhang

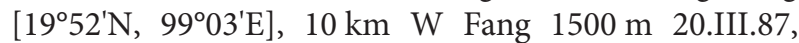
P. Schwendinger" (cAss).

Etymology: The specific epithet (Latin, adjective: halfbald) alludes to the chaetotaxy of the male sternite VIII.

Description: Body length 2.8-3.8 mm; length of forebody 1.7-2.0 mm. Coloration: head blackish-brown to black; pronotum brown to blackish-brown; elytra pale-brown to brown, with slightly and diffusely paler humeral angles and posterior margins; abdomen brown to blackishbrown with paler apex; legs yellow; antennae dark-yellow. Head (Fig. 69) approximately 1.25 times as broad as long; punctation coarse and very dense, only slightly less dense in posterior dorsal portion; interstices without microsculpture. Eyes very large, nearly extending to posterior angles of head. Antenna approximately $1.0 \mathrm{~mm}$ long.

Pronotum (Fig. 69) distinctly transverse, 1.05-1.07 times as broad as long and approximately 0.85 times as broad as head; punctation dense and coarse, similar to that of head; midline narrowly impunctate and usually with a fine median furrow in posterior half; interstices without microsculpture.

Elytra (Fig. 69) 1.00-1.05 times as long as pronotum; punctation dense and rather fine. Hind wings fully developed. Metatarsomere I slightly shorter than the combined length of II and III.
Abdomen narrower than elytra; punctation fine and dense; interstices with shallow transverse microsculpture; posterior margin of tergite VII with palisade fringe.

$o^{\text {* }}$ : sternite VII (Fig. 70) transverse, approximately 1.15 times as broad as long, and with moderately dense pubescence, in postero-median portion with a cluster of numerous short setae, posterior margin with an angular projection on either side, between these projections more or less distinctly concave; sternite VIII (Figs 71-72) oblong, in posterior portion impunctate and without pubescence, except for few setae along the middle, posterior excision of narrowly triangular shape and approximately 0.2 times as deep as length of sternite; aedeagus (Figs 73-74) $0.55-0.60 \mathrm{~mm}$ long; ventral process straight, rather stout, weakly dentate subapically, and apically very acute; internal sac with dark membranous structures.

Comparative notes: Based on the similar male sexual characters, N. semicalvus is closely allied to $N$. rougemonti and $N$. biangulatus. It differs from both of them by the broader body, the more transverse pronotum, the presence of a fine median furrow along the posterior half of the pronotal midline, the somewhat shorter elytra, and the stouter ventral process of the aedeagus with less pronounced subapical teeth, from $N$. rougemonti additionally by the much denser punctation of the forebody, the presence of angular projections at the posterior margin of the male sternite VII, and the presence of few setae along the middle of the posterior half of the male sternite VIII, from $N$. biangulatus also by the slightly denser punctation of the forebody, the distinctly transverse male sternite VII with more numerous short setae in the postero-median portion, the deeper posterior excision of the male sternite VIII, and the larger aedeagus.

Intraspecific variation: The male from Doi Angkhang is distinguished from those from the type locality by the slightly different shape of the male sternite VII (posterior margin more strongly concave between the angular projections). However, no additional differences were found suggesting that it should represent a different species.

Distribution and natural history: The known distribution is confined to two localities in northern Thailand (Map 6). The specimens were collected at altitudes of 900 and $1500 \mathrm{~m}$. 


\section{Neosclerus areolatus spec. nov.}

(Figs 75-83)

Type material: Holotype $0^{\star}:$ “THAILAND [26] - Doi Inthanon, Mae Aum, $18^{\circ} 31^{\prime} \mathrm{N}, 98^{\circ} 30^{\prime} \mathrm{E}, 1640 \mathrm{~m}$, moist evergr. forest, 11.I.2014, leg. Ob / Holotypus ơ Neosclerus areolatus sp. n. det. V. Assing 2015” (cAss).

Paratypes: $8 \sigma^{\star} \sigma^{\star}, 21$ 우 우 [1 $\sigma^{\star}, 1$ 울 infested with Laboulbeniales]: same data as holotype (cAss, MNHUB); 8 exs. [partly teneral]: "THAILAND: Chiang Mai, Doi Inthanon, 1650 m, 7.XI.85, Burckhardt-Löbl” (MHNG, cAss); 1 ex.: same data, but $1720 \mathrm{~m}$ (MHNG); 1 ex.: same data, but $1250 \mathrm{~m}, 6 . X I .85$ (MHNG); 2 ㅇ ㅇ: "THAILAND: Chiang Mai, Doi Angkhang [19² $\left.52^{\prime} \mathrm{N}, 9^{\circ} 03^{\prime} \mathrm{E}\right], 10 \mathrm{~km}$ W Fang 1500 m 20.III.87, P. Schwendinger" (MHNG); 3 우 우 [partly teneral]: "THAILAND: Chiang Mai, Doi Suthep, 1450 m, 4.XI.85, Burckhardt-Löbl” (MHNG, cAss).

Etymology: The specific epithet (Latin, adjective) alludes to the areolate punctation of the head and pronotum.

Description: Body length 3.2-4.0 mm; length of forebody 1.9-2.1 mm. Coloration: head blackish; pronotum darkbrown to blackish; elytra brown to blackish-brown, with the humeral angles indistinctly paler and the posterior margins usually broadly yellowish to reddish; abdomen blackishbrown to blackish; legs yellow; antennae dark-yellow.

Head (Fig. 75) approximately 1.25 times as broad as long; punctation umbilicate, moderately coarse and extremely dense on whole surface, including posterior dorsal portion, rendering dorsal surface matt (Fig. 76); interstices reduced to narrow ridges everywhere, with very shallow, nearly obsolete microsculpture visible only at high magnification. Eyes very large, nearly extending to posterior angles of head. Antenna approximately $1.1 \mathrm{~mm}$ long.

Pronotum (Fig. 75) transverse, approximately 1.05 times as broad as long and $0.86-0.88$ times as broad as head; punctation umbilicate, very dense, and coarse, coarser than that of head (Fig. 77); impunctate median band very narrow, often present only in posterior half, with fine but distinct furrow in posterior half; interstices very narrow, without microsculpture.

Elytra approximately as long as pronotum; punctation dense and distinct. Hind wings fully developed. Metatarsomere I approximately as long as the combined length of II and III.

Abdomen narrower than elytra; punctation fine and dense; interstices with shallow transverse microsculpture; posterior margin of tergite VII with palisade fringe.

$\mathrm{o}^{\top}$ : sternite VII (Figs 78-79) weakly transverse, approximately 1.05 times as broad as long, and with dense pubescence, in postero-median portion with an ill-defined cluster of slightly stouter and darker setae, posterior margin distinctly concave in the middle; sternite VIII (Figs 80-81) approximately as broad as long, anteriorly with an oblong median elevation with dense setae, in posterior portion depressed, impunctate and without pubescence, except for a band of setae along the middle, posterior exci- sion of triangular shape and approximately 0.25 times as deep as length of sternite; aedeagus (Figs 82-83) approximately $0.5 \mathrm{~mm}$ long; ventral process subapically abruptly narrowed and weakly curved, apically acute in lateral view; internal sac with short and stout sclerotized structures.

Comparative notes: Based on the morphology of the aedeagus (shapes of the ventral process and of the internal structures), as well as the similarly derived shapes and chaetotaxy of the male sternites VII and VIII, N. areolatus is closely allied to N. barbatulus, from which it differs by the distinctly broader body, the much denser and areolate punctation of the head and pronotum, the much narrower impunctate band on the pronotum, the less strongly modified pubescence in the postero-median portion and the more strongly concave posterior margin of the male sternite VII, the shape and chaetotaxy of the male sternite VIII (N. barbatulus: posterior excision less deep, posterior portion without setae along the middle), and by the smaller aedeagus ( $N$. barbatulus: approximately $0.55 \mathrm{~mm}$ ) with a ventral process of different shape both in lateral and in ventral view. For illustrations of N. barbatulus see Assing (2011a).

Distribution and natural history: The type specimens were found in several localities in northern Thailand at altitudes of $1250-1720 \mathrm{~m}$. The material from the type locality was collected by litter sampling in a moist evergreen forest. Some of the paratypes are teneral; two are infested with Laboulbeniales.

\section{Unnamed and unidentified species}

\section{Neosclerus spec. 1}

Material examined: Thailand: 1 , mountains $\mathrm{N}$ Umphang, Mae sot [?] Umphang, 1250 m, 10.II.1993, leg. Schwendinger (MHNG).

\section{Neosclerus spec. 2}

Material examined: Thailand: 1 ㅇ, $10 \mathrm{~km}$ W Wiang Pa Pao, Ban Huay Ya Sai, 780 m, 28.I.1988, leg. Schwendinger (MHNG).

\section{Neosclerus spec. nov.}

Material examined: India: 3 ㅇ + Kerala, Cardamon Hills, 46 km SE Munnar, Valara Fall, 25.XI.1972, leg. Besuchet, Löbl \& Mussard (MHNG, cAss).

Comment: The above females are distinguished from all named Neosclerus species based on external characters alone and undoubtedly represent an undescribed species. 
4. Catalogue of the named species of Neosclerus

\begin{tabular}{|c|c|c|}
\hline Species & Distribution & References \\
\hline albens spec. nov. & Sri Lanka & App \\
\hline areolatus spec. nov. & Thailand & App \\
\hline armatus Assing, 2011 & Taiwan: Hsinchu & A11a \\
\hline assamensis (CAMERON, 1931) & Northeast India: Assam, Meghalaya & A11a, A13, App \\
\hline atsushii SHIBATA, 1992 & Taiwan: Nantou & A11a \\
\hline barbatulus Assing, 2011 & Thailand; Burma; Laos; China: Yunnan & A11a, A13, App \\
\hline barbatus Assing, 2011 & Thailand; Burma & A11a, App \\
\hline biaculeatus Assing, 2014 & Taiwan: Nantou & A14 \\
\hline biangulatus spec. nov. & Thailand & App \\
\hline bicarinatus Assing, 2011 & Vietnam & A11a, App \\
\hline bifidus Assing, 2011 & Taiwan: Kaohsiung & A11a, A14 \\
\hline $\begin{array}{l}\text { brevipennis (CAMERON, 1943) } \\
=\text { brevipennis (COIFFAIT, 1978) } \\
=\text { houlberti (COIFFAIT, 1987) }\end{array}$ & Northeast India; Bhutan; Nepal & A11a, A13, App \\
\hline brevispinosus Assing, 2014 & Taiwan: Chiai & A14 \\
\hline carinatus Assing, 2011 & Taiwan: Pingtung & A11a \\
\hline configens Assing, 2011 & Taiwan: Nantou, Taoyuan & A11a \\
\hline daweianus spec. nov. & China: Yunnan & App \\
\hline discolor spec. nov. & Burma; Thailand & App \\
\hline dupleseriatus Assing, 2011 & Northwest India; Nepal & A11a, A11b, A13, App \\
\hline erubescens Assing, 2011 & Malaysia: Borneo: Sabah & A11a, App \\
\hline figens spec. nov. & China: Yunnan & App \\
\hline forficatus spec. nov. & Sri Lanka & App \\
\hline fortepunctatus CAMERON, 1924 & North India: Uttar Pradesh, West Bengal; Nepal & A11a, A11b, App \\
\hline fractus spec. nov. & Northeast India: Meghalaya: Khasi Hills & App \\
\hline $\begin{array}{l}\text { granulicollis CAMERON, } 1924 \\
=\text { frater CAMERON, } 1924\end{array}$ & North India: Uttar Pradesh, West Bengal; Nepal & A11a, A11b, App \\
\hline glaber Assing, 2011 & South China; Hongkong; Thailand; Malaysia & A11a, App \\
\hline hlavaci Assing, 2011 & China: Fujian, Jiangxi & A11a, App \\
\hline immutatus Assing, 2011 & Indonesia: Sumatra; Malaysia: Sabah & A11b, App \\
\hline inarmatus Assing, 2011 & Taiwan: Hsinchu & A11a \\
\hline incisus Assing, 2011 & China: Guangxi & A11a, App \\
\hline javanus (BERNHAUER, 1920) & Indonesia: Java & A11a, App \\
\hline khasicus spec. nov. & Northeast India: Meghalaya: Khasi Hills & App \\
\hline macer Assing, 2013 & Laos; Thailand & A13, App \\
\hline nigerrimus (KRAATZ, 1859) & Sri Lanka & A11a, App \\
\hline obscurus Assing, 2013 & Northeast India: Assam & A13, App \\
\hline praeacutus Assing, 2011 & China: Yunnan; Thailand; Laos? & A11a, A11b, App \\
\hline rimatus Assing, 2011 & China: Guangxi & A11a, App \\
\hline revolutus spec. nov. & South India & App \\
\hline rougemonti Assing, 2011 & Thailand & A11a, App \\
\hline sagittatus spec. nov. & Northeast India: Meghalaya: Khasi Hills & App \\
\hline
\end{tabular}




\begin{tabular}{|l|l|l|}
\hline \multicolumn{1}{|c|}{ Species } & \multicolumn{1}{|c|}{ Distribution } & \multicolumn{1}{c|}{ References } \\
\hline schillhammeri Assing, 2011 & Burma & A11a, App \\
\hline $\begin{array}{l}\text { schuelkei Assing, 2011 } \\
\text { semicalvus spec. nov. }\end{array}$ & China: Yunnan; Laos; Burma & A11a, A13, App \\
\hline $\begin{array}{l}\text { smetanai Assing, 2011 } \\
\text { trisinuatus spec. nov. }\end{array}$ & Thailand & App \\
\hline
\end{tabular}

The articles listed in the references column are abbreviated as follows: A11a = Assing (2011a); A11b = Assing (2011b); A13 = Assing (2013); A14 = Assing (2014); App = present paper. References containing descriptions and/or illustrations are given in bold print.

\section{Acknowledgements}

I am indebted to the colleagues indicated in the material section for the loan of material. Guillaume de Rougemont (Oxford) drew my attention to the presence of more than 500 previously unrevised specimens in the collections of the MHNG.

\section{References}

Assing, V. 2011a: A revision of the genus Neosclerus CAmeron (Coleoptera: Staphylinidae: Paederinae). - Beiträge zur Entomologie, Keltern 61 (1): 89-148.

Assing, V. 2011b: A revision of the genus Neosclerus Cameron. Supplement 1 (Coleoptera: Staphylinidae: Paederinae). - Beiträge zur Entomologie, Keltern 61 (1): 149-153.

Assing, V. 2013: A revision of Neosclerus CAmeron III. Two new species from India and Laos, and additional records (Coleoptera: Staphylinidae: Paederinae). Linzer Biologische Beiträge 45 (2): 1549-1559.

Assing, V. 2014: A revision of Neosclerus CAmeron IV. Two new species and additional records from Taiwan (Coleoptera: Staphylinidae: Paederinae). - Linzer Biologische Beiträge 46 (2): 1097-1101. 